\title{
Tewa Red and the Puebloan Diaspora: The Making of Ledbetter Red
}

\author{
Margaret Beck ${ }^{\mathrm{a}}$, Sarah Trabert ${ }^{\mathrm{b}}$, David V. Hill ${ }^{\mathrm{c}}$, and Matthew E. Hill, Jr. ${ }^{\mathrm{d}}$ \\ ${ }^{\mathrm{a}}$ Department of Anthropology, University of Iowa, 114 Macbride Hall, Iowa City, Iowa, 52242, \\ USA; margaret-beck@uiowa.edu \\ ${ }^{\mathrm{b}}$ Department of Anthropology, University of Oklahoma, 455 West Lindsey, Dale Hall Tower \\ 521, Norman, OK, 73019, USA; strabert@ ou.edu \\ ${ }^{c}$ Department of Sociology and Anthropology, Metropolitan State University of Denver, P.O. Box \\ 173362, Campus Box 28, Denver, CO, 80217-3362; dhill1@att.net \\ ${ }^{\mathrm{d}}$ Department of Anthropology, University of Iowa, 114 Macbride Hall, Iowa City, Iowa, 52242, \\ USA; matthew-e-hill@uiowa.edu
}

Corresponding author: Margaret Beck; margaret-beck@uiowa.edu

\begin{abstract}
In the $17^{\text {th }}$ and early $18^{\text {th }}$ centuries, Native American potters in the vicinity of the Scott County Pueblo (14SC1) in western Kansas produced a local copy of unpainted Tewa red ware known as Ledbetter Red. We examine the red-slipped unpainted ceramics from 14SC1 and two nearby sites, 14SC304, and 14SC409, using macroscopic data on slip and paste attributes, petrographic data on inclusions, and oxidation data on slip and paste colors to compare Ledbetter Red with Tewa Red and with the ancestral Apache ceramics native to the study area, and also to evaluate differences in Ledbetter Red between sites. Changes in the execution of Ledbetter Red between earlier (14SC1) and later (14SC304 and 14SC409) sites may represent the work of newly arrived Puebloan potters and then their descendants raised in ancestral Plains Apache territory. Although some Tewa Red traits were deemphasized or abandoned in Ledbetter Red over time, the red slip was maintained and actually improved in quality in later examples. The highly visible red color might have been symbolically the most important aspect of Ledbetter Red bowls, reflecting the ethnic and historical complexity of these protohistoric Plains communities.
\end{abstract}

\section{Keywords}

US Great Plains, US Southwest, Northern Rio Grande, Scott County Pueblo, Tewa Red, Ledbetter Red, ceramics, petrographic analysis, compositional analysis, oxidation analysis 


\section{Introduction}

Throughout the turbulent Spanish colonial period, native people in northern New Spain often left large settled communities as refugees, migrants, or captives (Brooks 2002; Dozier 1954;

Ferguson and Preucel 2005; Forbes 1994; Preucel 2002; Spicer 1962). Some of those moving were Puebloan women who joined Plains Athabaskan groups and left an archaeological trace through the ceramic vessels they made in their new territories (Beck and Trabert 2014; HabichtMauche 1987, 2000, 2008). We have strong evidence of Puebloan potters at multiple sites in the vicinity of the Scott County Pueblo (14SC1) in western Kansas (Figure 1), where some of the $17^{\text {th }}$ and early $18^{\text {th }}$ century residents produced a local copy of unpainted red ware as made in Tewa-speaking Puebloan communities in New Mexico. James Gunnerson $(1998,2006)$ initially identified this local copy of Tewa Red during a 1965 field visit to the area, naming it "Ledbetter Red," but he never published a description and the type was largely forgotten. This evidence for local manufacture of a Puebloan ceramic type by local residents—and the implications for population movement from the Rio Grande region — is an important counterpoint to other literature on Plains-Pueblo relationships, which often focuses on trade (e.g., Baugh and Nelson 1987; Spielmann 1983, 1991).

In this paper, we examine the red-slipped unpainted ceramics from 14SC1, 14SC304, and 14SC409, describing Ledbetter Red and placing it within spatial, temporal, and cultural context. We use macroscopic data on slip and paste attributes, petrographic data on mineralogy inclusions, and oxidation data on slip and paste colors to compare Ledbetter Red with Tewa Red and with the ancestral Apache ceramics native to the study area, and also to evaluate differences in Ledbetter Red between sites. We argue that changes in the execution of Ledbetter Red 
between earlier (14SC1) and later (14SC304 and 14SC409) sites may represent the work of newly arrived Puebloan potters and then their descendants raised in ancestral Plains Apache territory. One or more generations later, it was the red interior slip on Ledbetter Red bowls that persisted most clearly and may have been a potent reminder of Puebloan heritage and identity.

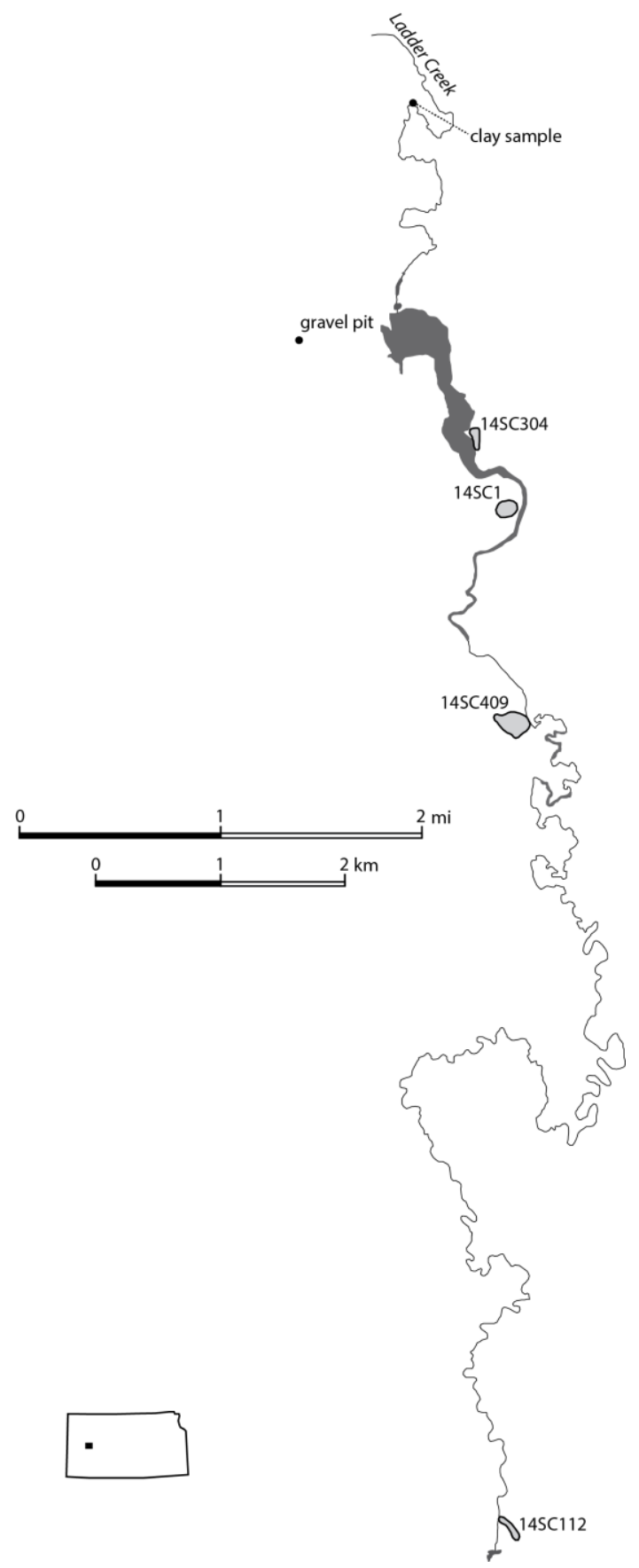

Figure 1. Archaeological sites and modern raw material sample locations in the study area. 


\subsection{Archaeological sites in the study area: 14SC1, 14SC304, and 14SC409}

Red ware was produced in this part of the eastern High Plains after interaction with, and probably some population movement from, Puebloan communities in the northern Rio Grande region of New Mexico. Marked evidence of interaction and migration appears at the Scott County Pueblo (14SC1), so named for the 7-room stone and adobe pueblo that is the northeasternmost pueblo in the United States. This is in spite of the distance between the Scott County Pueblo and Taos Pueblo, the closest pueblo in the northern Rio Grande region; one documented journey on horseback (that of Juan de Ulibarri) between the two areas covered over $400 \mathrm{~km}$ and took 23 days (Gunnerson 1992; Schroeder 1974). This was historically Plains Apache territory, and an ancestral Plains Apache (Dismal River aspect) occupation predated and may have continued alongside the pueblo at $14 \mathrm{SC} 1$. Women from one or more northern Rio Grande pueblos apparently moved to western Kansas, joining the existing Athabaskan-speaking residents and making pottery at the site using techniques from their natal communities (Beck and Trabert 2014).

Recent stratigraphic analysis of the AMS radiocarbon dates at 14SC1 (Hill et al. n.d.) suggest at least two occupation episodes, one including the pueblo and one including the intact pit features and associated artifacts below the pueblo. Possible date ranges of the earlier features, based on the calibrated dates, are AD 1463-1528 and AD 1552-1634. We argue for the AD 15521634 range, based on the recovery of a Robin's egg blue bead (Type IIa40) from exavations slightly south of the pueblo. It is difficult to date the construction of the pueblo, but dates from four borrow pits, probably used to quarry adobe for the construction of the pueblo, produced two possible intercepts: AD 1526-1556 and AD 1632-1651. The pueblo structure was later burned, 
which charred a large quanity of corn on the floor of the pueblo and other floor artifacts and features. The three dates associated with burning the pueblo also provide at least two possible age ranges: AD 1652-1681 and AD 1739-1802. The AD 1652-1681 range appears most likely, given the absence of horse bones and artifacts clearly dating to the $18^{\text {th }}$ century. The painted nonlocal ceramics from the site, including Tewa Polychrome (AD 1650-1750) and Rio Grande Glaze Ware (manufactured until approximately AD 1700) also support occupation in the second half of the $17^{\text {th }}$ century (dates from Wilson 2010).

We compare the red-slipped unpainted ceramics from 14SC1 to those from two nearby sites, 14SC304 and 14SC409. 14SC304 is the site where James Gunnerson originally identified the ceramic type Ledbetter Red. He excavated here in 1965, recording it as 14SC111 and naming it the Ledbetter site. He never published the excavation methods or results, although he briefly mentions the site in print (Gunnerson 1968, 1998). In his field notes, he states that they excavated a 'typical' Dismal River structure, $3.6 \mathrm{~m}$ in diameter, with five posts surrounding a central hearth (Hoard 2009). The limited artifacts recovered include lithic debitage, stone scrapers, groundstone shaft abraders, and ceramics. Further investigation of this site by the Kansas Historical Society and the University of Iowa suggests that although some cultural materials remain, the site has been too significantly disturbed to warrant further excavation (Hoard 2009; Trabert and Hill n.d.). One AMS radiocarbon date at 14SC304 (Hill et al. n.d.) indicate occupation range between AD 1680-1730, suggesting that the occupation here either overlapped with the later occupation at 14SC1 or immediately followed it.

14SC409 is located several hundred meters south of 14SC1 and was originally recorded in 1976 as a 9,400 square meter scatter of pottery, lithic flakes, and bones. Limited excavations were conducted by the Kansas Historical Society in 2009 (Hoard 2009) and the University of 
Iowa in 2013 and 2014 (Trabert 2015; Trabert and Hill n.d.). The recovered artifacts include ceramics, lithics, faunal remains, and Olivella dama shell beads. Two AMS radiocarbon dates indicate an occupation date range between AD 1680-1730 (Hill et al. n.d.). This date range is supported by the recovery of a French gunflint at the site in 2009 dating to AD 1675-1800 (Hoard 2009). 14SC409 was probably occupied at roughly the same time as 14SC304 and the end of the occupation at $14 \mathrm{SC} 1$.

\subsection{Early description of Ledbetter Red}

Recalling his 1965 field visit to the Scott County Pueblo area, Gunnerson (2006:625) writes, "One of the Dismal River house sites (14SC111 [now 14SC304]), brought to our attention by Bill Ledbetter, was especially interesting. From it we recovered locally made red-painted sherds, apparently in imitation of Tewa Pueblo red ware. This new type we named Ledbetter Red." This is the most detailed discussion of Ledbetter Red to appear in Gunnerson's published work, as he never mentions this type in his discussions of regional ceramics (Gunnerson 1968, 1987).

Among James Gunnerson's documents curated at the Kansas Historical Society are some observations on Ledbetter Red, in the form of handwritten notes (dated February 6, 1971) and also three typed pages titled "Description of New Pottery Type" that summarize his notes. Excerpts are provided below (with emphases added and typographical errors corrected):

Distribution: Known only from Ledbetter site [14SC304] (77 sherds out of 890 recovered at site) Time period: $1675 ?-1725 ? \ldots$

Surface treatment: Smoothed and incompletely polished. Very thin red slip or wash applied before polishing and firing. . .

Temper: Moderate amounts of fine rounded sand. A few particles up to about 1 $\mathrm{mm}$. in diameter 
Color: Paste usually dark gray to black, sometimes light gray to buff. Slip is various shades of red from buff to orange to moderately bright red. . .

Vessel form: No restorable vessels found, but sherds suggest only bowls. . . Comparisons: The Ledbetter Red sherds appear to be identical in paste, tempering, and thickness to the more abundant (91\%) gray utility ware at the site. This is what Wedel [1959:441] calls Scott Plain. . . Ledbetter Red is much smoother and much more polished than is Scott Plain.

Ledbetter Red could be a local attempt to imitate Tewa red wares which do show up at other Plains Apache sites although no sherds were found the Ledbetter site. Tewa Red wares, however, have a thicker slip, are much better polished and have a paste that is nothing like that of Ledbetter Red. The range of color (red) in the latter is apparently much greater than one finds on Tewa Red. Geneseo Red Filmed (Wedel 1949:89) is apparently similar in paste, but differs in vessel form (small-mouthed, globular vessels), surface treatment (cord roughened and simple stamped as well as carefully smoothed), lip form (rarely flattened), and nature of pigment (often "fugitive"). It is possible, however, that the inspiration for the use of red pigment of Ledbetter Red did come from Geneseo Red Filmed.

Gunnerson's observations have also been summarized by Hoard (2009:55-56). “Geneseo Red Filmed" as referred to by Gunnerson is a ceramic type defined for the contemporaneous Little River focus of the Great Bend aspect (ancestral Wichita) to the east in central Kansas (Blakeslee and Hawley 2006; Wedel 1959).

\subsection{Tewa red-slipped unpainted ceramics and regional copies}

The closest locales with significant red ware production were in the Tewa-speaking communities of the northern Rio Grande, where potters made unpainted red and black vessels by roughly AD 1600 (Schaafsma 2002; Warren 1977). Tewa Red ceramics have been reported from indigenous and vecino households in northern New Mexico into the mid-eighteenth century (Ferg 1984; Levine 2004; Warren 1976).

This red-slipped unpainted pottery has been previously termed Posuge Red (Mera 1939:12) and is technologically identical to the polished black ceramics with the exception of the 
final smudging of the vessel surface (Harlow 1973). "Posuge Red (Tewa Red)" is the only redslipped unpainted type defined for the Northern Rio Grande and Galisteo Basin in a recent guide to archaeological ceramic identification (Wilson 2010). Mera's type name "Posuge Red" was initially defined for a specific vessel form (jars with flaring rims), however. Posuge Red, like many other post-contact Puebloan ceramic types (e.g., Batkin 1987; Frank and Harlow 1990; Harlow 1973), was created by examining whole vessels, complicating efforts to apply it to fragmented sherd collections (Wilson 2011:223). Schasfsma (2002) has therefore argued for using the term Tewa Red rather than Posuge Red in sherd analyses. For similar reasons, Ellis (1964) substituted the term San Juan Red for Posuge Red. We primarily use "Tewa Red" in this paper but use it interchangeably with "Posuge Red," given that "Posuge Red" is still used in the ceramic type collections in the H. P. Mera Room (Laboratory of Anthropology, Museum of Indian Arts and Culture, Santa Fe, New Mexico) consulted for this project.

Tewa Red (Schaafsma 2002; Wilson 2010), also known as "Tewa Polished Red" (Wilson 2011), has "at least one surface that exhibited a red polished slip without evidence of other decoration," a slip that is "bright red to maroon and. . . is usually well polished" and tempered with "fine tuff" (Wilson 2011:225). The "polishing with conspicuous stone strokes. . . [gave] Tewa pottery its characteristic appearance for hundreds of years" (Harlow 1973:39). Variations on Tewa Red include Tewa Buff-Tan (Schaafsma 2002:149), an unslipped variety, and Tewa Brown and Tewa Maroon, which are probably not separate types but reflect the presence of intentionally unslipped areas on vessels or changes in red slip color on Tewa Red due to firing conditions (Schaafsma 2002:149-150). Tewa Red sherds may be confused with unpainted redslipped fragments of Tewa Polychrome (Schaafsma 2002). 
Volcanic materials such as ash, tuff, and pumice distinguish the pastes of Tewa area ceramics. These materials come from the Tesuque formation, which outcrops discontinuously across the Española Basin and contains zones of fine white volcanic ash (Galusha and Blick 1971). The use of ash, tuff, and pumice as temper is documented ethnographically and archaeologically from the nearby Tewa-speaking and ancestral Tewa pueblo communities (Habicht-Mauche 1993; LeFree 1975; Wilson 2011). LeFree (1975:14) notes that the fine volcanic tuff used as temper by Santa Clara potters is "visible as white strata at the rims of most of the hills in the area," which is a good description of Tesuque formation ash zones. A ceramic thin section made using clay and ash provided by a modern San Ildefonso potter strongly resembles the paste of thin sections of Abiquiu Black-on-white (AD 1375-1450) from fourteenth- and fifteenth-century Arroyo Hondo, located about five miles south of Santa Fe (Habicht-Mauche 1993:81; Vint 1999). In Schaafsma's (2002:147, 152) sample of ceramics from the Abiquiu Reservior area in the Chama Valley of New Mexico (roughly $100 \mathrm{~km}$ northwest of Santa Fe), 99 percent of the non-culinary Tewa ceramics (Tewa Red, Tewa Black, Tewa Gray, Tewa Black-on-white, and the polychrome types) have tuff temper.

Although Tewa Red originates in the Española Basin, it was copied elsewhere in the northern Southwest, notably at Picuris and Pecos Pueblos. It appeared at Picuris after AD 1600, both as vessels from the Tewa area and also as locally made copies (Warren 1976:B-43). The exchanged Tewa Red ceramics at Picuris "are tempered with large glassy spicules of tuff similar to that found in deposits on and near the Pajarito Plateau. This tuff temper is identical to the tempering material found in sherds of the same types collected by Herbert Dick at San Juan Pueblo" (Dick et al. 1999:90). In contrast, the "local variety is not as well polished, is softer, and has in the paste abundant mica inclusions, which are lacking in the true San Juan Red [Tewa 
Red]" (Dick et al. 1999:90-91). Red-slipped unpainted vessels known as Plain Red appeared towards the end of occupation at Pecos Pueblo, "late in Glaze V" (Glaze E, AD 1515-1700; Wilson 2010:66) and "remained in fashion until the abandonment of the pueblo" (Kidder 1936:287). Plain Red vessels at Pecos are typically tempered with quartz-feldspar sand with mica flakes, and often have coarser grains of siltstone (up to 2-3 mm) as well (Shepard 1936:541). Vessels similar to Tewa Red were also made farther south, near Albuquerque (Wilson 2010:14) and in the Salinas Basin (Warren 1977:366).

\section{Sample and methods}

Our data on the 14SC1, 14SC304, and 14SC409 red-slipped unpainted ceramics were collected through macroscopic observations (slip color, paste color, surface treatment) and petrographic and oxidation analyses. We make comparisons with ceramics known to be locally produced (Dismal River Gray Ware) from 14SC1 and ceramics known to be manufactured in the Española Basin in the northern Rio Grande (Tewa Red and Tewa Polychrome) from the ceramic type collections of the H. P. Mera room, Museum of New Mexico.

The 14SC1 ceramics analyzed for this paper were recovered by the Kansas Historical Society (KSHS; see Beck and Trabert 2014). The KSHS collection includes 36 red-slipped unpainted sherds ( 6 rim, 30 body). These sherds make up the majority of the 51 "Puebloan slipped and/or painted sherds" (8 rim, 43 body) identified by Beck and Trabert (2014:Table 4), which are less than one percent of the ceramics recovered from 14SC1. Most of the remaining "Puebloan" sherds identified by Beck and Trabert (2014:Table 4; 11 body) exhibit black paint and appear to be ash/pumice/tuff-tempered fragments of Tewa Polychrome or a similar type (Wilson 2011). Two additional body sherds were initially identified as red-slipped unpainted 
ceramics and counted as such in Beck and Trabert (2014:Table 4), but later determined through the detailed analyses described below to be unslipped. The remaining two rim sherds recorded by Beck and Trabert (2014:Table 4) have black paint but no visible slip and cannot be assigned to a known type.

The 14SC304 and 14SC409 ceramic collections are also curated by the KSHS. The collection from 14SC304 includes 47 red-slipped unpainted sherds ( 4 rim, 43 body). This is 30 fewer sherds than observed by Gunnerson in his original type description for Ledbetter Red, and it is possible that not all of the sherds he collected are held by the KSHS. The collection from 14SC409 includes 65 red-slipped unpainted sherds ( 5 rim, 60 body).

Finally, we collected clay and sand samples from the area around 14SC1 for comparison in the macroscopic and petrographic analysis (Trabert 2015; Trabert et al. 2015). The clay samples were taken from a profile along Ladder Creek, approximately $4 \mathrm{~km}$ north of $14 \mathrm{SC} 1$, and the sand was collected from one of the surrounding quarries mining the Ogallala Formation sand and gravel (Figure 1).

\subsection{Petrographic analysis and other microscopy}

As part of her regional work with Dismal River ceramics, Trabert (2015; Trabert et al. 2015) submitted samples of Dismal River Gray Ware, micaceous ceramics, and red-slipped unpainted ceramics from 14SC1, 14SC304, and 14SC409 for petrographic analysis. David V. Hill collected the petrographic data used to define compositional groups, including mineral grain identification, grain shape and size, and percentage of inclusions, following Matthew et al. (1991) and Terry and Chilingar (1955; see Hill's report in Trabert 2015, Appendix B; Trabert et al. 2015). Beck examined the un-sectioned remnants of the petrographic sample, using a nonpolarizing binocular 
microscope, identifying criteria to assign the remaining red-slipped sherds in this study to one of the defined groups.
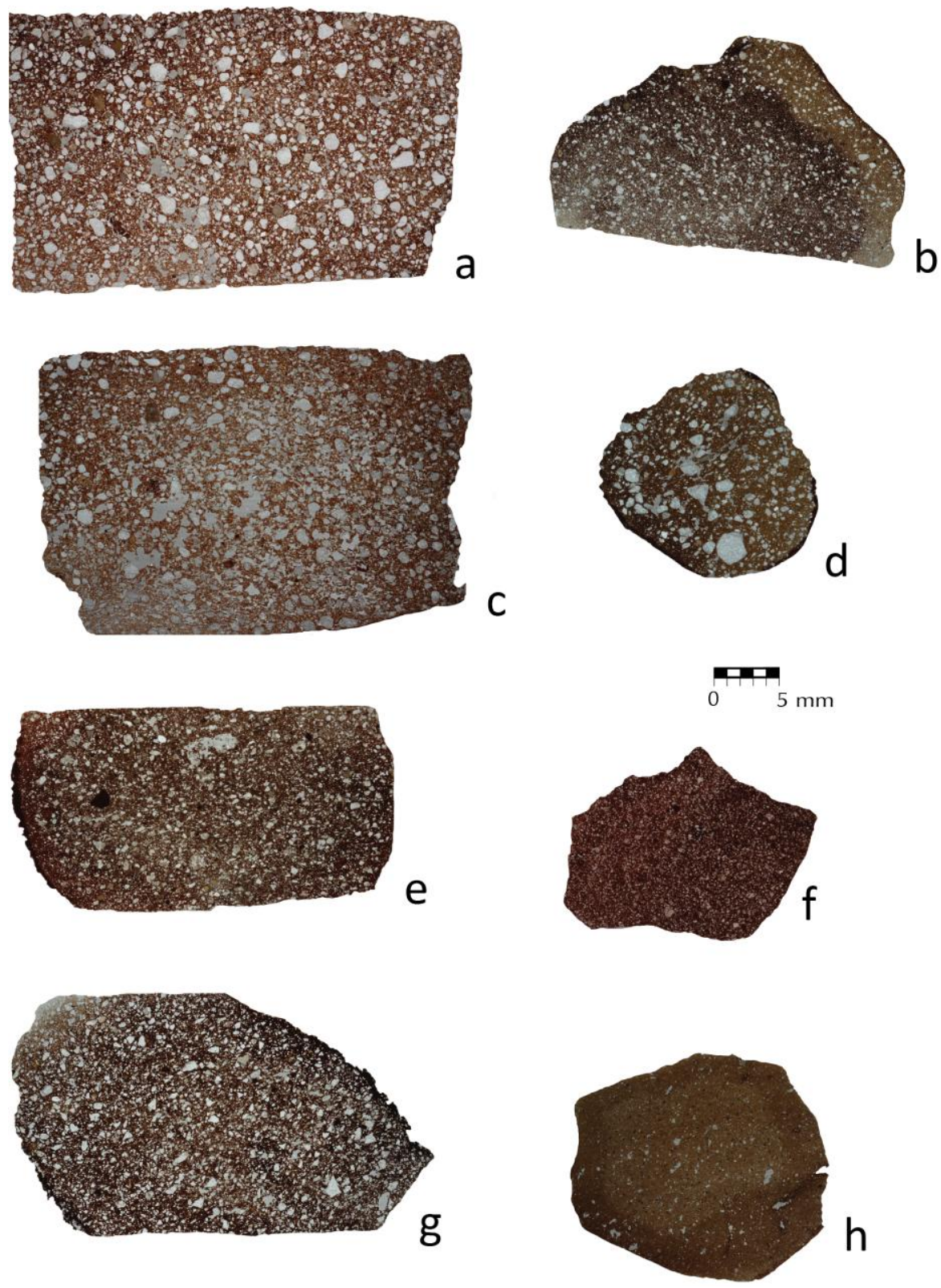

Figure 2. Examples of compositional groups from 14SC1: (a) arkosic sand, coarse paste group (Dismal River Gray Ware, SC-5, no catalog number); b. arkosic sand, very fine paste group (indeterminate plain, SC-39, cat 553); (c) arkosic sand, coarse paste group (Ledbetter Red, SC22, cat 24115); (d) arkosic sand, coarse paste group (Ledbetter Red, SC-51, cat 11273); (e) sand/sandstone group (indeterminate unpainted red-slipped, SC-41, cat 23196); (f) sand/sandstone group (Pecos Glaze or Plain Red, SC-15, cat 27523); (g) biotite granite group (SC-9, cat 9948); (h) ash/pumice/tuff group (Tewa Polychrome, SC-11, cat 1925). 
The five compositional groups, based primarily on dominant mineralogy and inclusion size range, are: arkosic sand, coarse paste; arkosic sand, very fine paste; biotite granite; sandstone/sand; and ash/pumice/tuff (Figure 2). The "coarse paste" group (Figure 2a, c, d) has inclusions up to coarse or very coarse sand in size; the "very fine paste" group (Figure 2b) has inclusions up to fine sand in size. The "arkosic sand, coarse paste," if not also the "arkosic sand, fine paste" group, represents use of local materials (Trabert 2015; Trabert et al. 2015) based on comparison with our sample of Ogallala Formation sands. Diffendahl (1984) describes sediment and sediment sources for the Ogallala Formation. The sand grains from the Ogallala, as observed in the quarry sample, ranged in size from very fine sand to gravel in size, with rounded to subrounded grains of arkosic (quartz and feldspar) composition. They also included trace amounts of welded tuff (ash and pumice), basalt, limestone, and caliche, all materials also found in small amounts in "arkosic sand, coarse paste" ceramics.

Attributes of the "arkosic sand, coarse paste" group are also consistent with petrographic observations of clay in the study area, particularly the appearance of reddish brown pizolites and caliche in the paste. Grain size ranged up to very fine sand in our modern clay samples. In addition to trace amounts of sub-angular to rounded quartz, samples also had alkali feldspar, biotite, reddish brown clay pizolites (fine to medium sand in size) and caliche (coarse sand in size). Snail shells were not observed in the petrographic analysis of Ladder Creek clays, probably because the clay was ground before it was made into test tiles to be fired and thin-sectioned. Small snail shells are visible macroscopically in unprocessed samples of the same Ladder Creek clays, however. They were also found in buried soils elsewhere along Ladder Creek, including at the nearby site 14SC112 to the south (Figure 1; Mandel 2007: Table 2). 
Nonlocal materials are probably represented by the biotite granite, sandstone/sand, and ash/pumice/tuff groups. Sherds in the "biotite granite" group (Figure 2g) contained some biotite granite fragments with attached quartz and feldspar, and grains were angular rather than the rounded to subrounded grains seen in the "arkosic sand" groups. At least some of the biotite granite tempered ceramics may have been made on the High Plains, perhaps near the Front Range in Colorado or the Laramie Mountains in Wyoming (Trabert et al. 2015).

The sandstone/sand group (Figure 2e, f) may represent vessels manfactured in the vicinity of Pecos, as sandstone and siltstone outcrops around Pecos were used throughout the glaze ware sequence there (Shepard 1936:517). Sand and sandstone are present in over 90\% of samples of Late Group Rio Grande Glaze Ware at Pecos and in roughly 10\% of the samples from the Rio Arriba district around the modern Tewa pueblos as well (Shepard 1942).

Pastes in the "ash/pumice/tuff” group (Figure 2h) contain large quantities (around 50 percent of the matrix) of these inclusions and may also have up to three percent of quartz sand up to fine sand in size. These pastes are very fine in texture and contain much larger quantities of ash, pumice, or tuff than the occasional grains found in Ogallala formation sands. As noted earlier, they represent vessels manufactured in or around the Española Basin.

\subsection{Slip and paste colors: oxidation analysis and other observations}

The original slip and paste colors were recorded for all red-slipped sherds analyzed from 14SC1, 14SC304, and 14SC409. Beck conducted oxidation analysis on ten red-slipped body sherds (six "arkosic sand, coarse paste" sherds and four with sandstone/sand) from 14SC1, following previously described methods (Roper et al. 2010, Beck et al. 2012; see also Beck 2006). All original and oxidized colors are reported here in Munsell notations and color names from the 
Year 2000 Revised Washable Edition of the Munsell Soil Color Charts. One additional term used here that is not used in the Munsell charts is "buff," a label frequently applied by ceramic analysts to describe very light ceramic pastes and surfaces (Beck 2006; Beck et al. 2012). "Buff”' colors, as defined in this study, had a Munsell value (lightness) of 7 or greater. This is a higher value than used in previous studies (Beck 2006; Beck et al. 2012), but better distinguishes unusually pale pastes from the bulk of Plains ceramic pastes, which frequently oxidize to colors with a value of 6 (Roper et al. 2010: Tables 4, 6).

\subsection{Dismal River Gray Ware comparison}

Local red-slipped ceramics might have similar pastes to other local ceramics, as originally suggested by Gunnerson in his unpublished notes on Ledbetter Red. We drew comparative data on paste color and mineral inclusions from a small sample of Dismal River Gray Ware (Baugh and Eddy 1987; Brunswig 1995), so named for its typical dark gray to brown color produced by firing in reduced conditions. Eight Dismal River Gray Ware body sherds were included in the broader petrographic and instrumental neutron activation analyses reported by Trabert (2015; Trabert et al. 2015) and analytically shown to be produced in our study area. Beck conducted oxidation analysis on all eight sherds, using the same methods as for the red-slipped unpainted sherds.

All eight of these sherds, as well as the other 12 Dismal River Gray Ware sherds analyzed only by petrography, fall into the "arkosic sand, coarse paste" group (see Hill's report in Trabert 2015, Appendix B). Five of these sherds are grouped into Trabert's (2015; Trabert et al. 2015) INAA Group 3, along with almost all of the analyzed Dismal River Gray Ware recovered from Kansas. Group 3 is assumed here to be local to the 14SC1 area, perhaps unlike 
Group 2 (where Dismal River Gray Ware from Nebraska clusters) and Groups 1 and 5 (which contains micaceous ceramics from Dismal River sites in Kansas and Nebraska; Trabert 2015; Trabert et al. 2015).

\subsection{Tewa red-slipped ceramics comparison}

Beck visited the H. P. Mera room at the Museum of New Mexico to record slip color, paste color, and surface treatment on a sample of historical-period Tewa ceramics from the type collection. Although not all of these ceramics were recovered from Tewa communities, their presence in the type collection was taken as evidence that they were representative examples of Tewa ceramic types. The 24 sherds recorded in the type collection include Posuge Red [Tewa Red] and Tewa Polychrome from LA 38 (Cuyamungue) and Tewa Polychrome from LA 625 (Pecos Pueblo), LA 16, LA 34 (Cochiti Spring; Warren 1977), and LA 295 (Old Cochiti; Warren 1977). Some additional sherds of Tewa Polychrome were unlabeled. Two small vessels missing provenience information and labeled "Nambe Buff" (Tewa Buff; Wilson 2011) were also recorded.

Oxidation analysis was not possible with this comparative sample, so we have data only on the original slip and paste colors. In oxidation analysis of this sample and others, colors that were "buff" (with a value of 7 or greater) before oxidation analysis remained buff afterwards (see Beck 2006 for a discussion of color changes during oxidation analysis). We therefore assume that buff pastes observed on sherds in the H. P. Mera Collections would remain buff even after refiring. 


\section{Results and discussion}

\subsection{Tewa Red from the Tewa Basin: the H. P. Mera collections}

As noted in previous type descriptions (e.g., Schaafsma 2002; Wilson 2010; Wilson 2011), Tewa potters emphasized bright red slips with high polish on Tewa Red vessels. Slips on Posuge Red

[Tewa Red] vessel fragments in the H. P Mera collections appeared on both surfaces, only on the interior, or on the exterior with a smudged and polished interior. In all cases, the red slip on Tewa sherds had a polished, glossy appearance, with visible polishing striations.

As recorded by Beck for this sample, the original red slip color on Tewa Polychrome is usually red (10R 4/6, 10R 5/6), with a few cases of weak red (10R 5/4, 10R 4/4, 10R 4/3) and pale red (10R 6/4). In a few cases, slips vary from red to light brown (7.5YR 6/4) or light reddish brown (5YR 6/4) on the same sherd. Posuge Red [Tewa Red] slips are red (10R 5/6), weak red (10R 5/3, 10R 5/4), light red (10R 6/6) or reddish brown (5YR 4/3). The reddish brown color is unusual and associated with a smudged and polished vessel interior.

Tewa ceramic pastes are often "buff” in color, with Munsell values over 7. Original paste colors for Tewa Polychrome sherds in the H. P. Mera collections are mostly pink (5YR 7/4, 7.5YR 7/4) with some examples of reddish brown (5YR 5/4), light reddish brown (5YR 6/4), reddish yellow (5YR 6/6), and light brown (7/5YR 6/4) pastes. One sherd had a paste varying from pink to light reddish brown along with a carbon core. Almost all of the Tewa sherds analyzed had a carbon core, frequently a thick one. Posuge Red [Tewa Red] pastes were light reddish brown or pink, and the two Nambe Buff vessels had pink (7.5YR 7/4) pastes. 


\subsection{Paste composition and provenance at14SC1, 14SC304, and 14SC409}

Of the 148 red-slipped unpainted sherds from these three sites, only eight body sherds (all from 14SC1) might belong to vessels manufactured in the northern Rio Grande rather than the study area. Two body sherds of the eight contain ash/pumice/tuff temper. Both are extremely small, with missing interior surfaces and red-slipped exteriors.

Six body sherds - two of which were included in the petrographic analysis (samples SC15 and SC-41; see Hill's report in Trabert 2015, Appendix B)—have sandstone/sand temper. Four of the six have smudged and polished interiors with red-slipped exteriors, and two are slipped on both the interior and exterior. As noted earlier, at least some of these may originate in the Pecos area. One of the sherds slipped on both surfaces (SC-15; Figure 2f) had "Pecos Glaze" written on it in pencil, although no glaze paint or other decoration was visible on the surface. This sherd might have been assigned to the Pecos area by a previous analyst based on the sandstone inclusions. If this provenance is accurate, the sherd may represent a Plain Red (Shepard 1936:541-542) vessel rather than the Glaze E type Pecos Glaze Polychrome (AD 15151700; Wilson 2010:66). The average and maximum grain size observed in SC-15 compare well with grain size descriptions for both Pecos types (Shepard 1936:512, 541). The other sherd in this group to be analyzed petrographically (SC-41; Figure 2e) has markedly coarser paste containing poorly sorted sandstone, rather than the well sorted sandstone observed in SC-15, and may have a different provenance.

All of the remaining analyzed sherds (Tables 1-3) - five of which were included in the petrographic analysis - fall into the "arkosic sand, coarse paste" group, along with the locally produced Dismal River Gray Ware sherds. We consider these red-slipped, unpainted ceramics to 
be local copies of Tewa Red as argued by Gunnerson, and refer to them throughout the rest of this paper as Ledbetter Red.

Arkosic sand is very widely available in the Plains, the northern Rio Grande region, and elsewhere, so arkosic sand alone is no guarantee of local production. Arkosic sand was used for temper in $80 \%$ of the Late Group of Rio Grande Glaze Ware samples at Picuris (Shepard 1942). Red-slipped ceramics similar to Tewa Red were also made near Albuquerque with sand temper (Wilson 2010:14), and Plain Red ceramics from Pecos may have only sand without siltstone inclusions (Shepard 1936). In Ledbetter Red ceramics, however, the arkosic sand is often accompanied by occasional particles of tuff and pumice, basalt, and caliche as observed in the Ogallala Formation sand samples. The size range of inclusions (up to coarse sand) is also consistent with the Dismal River Gray Ware sherds. Finally, the broken edges of five Ledbetter Red sherds from 14SC304 reveal snail shell similar to the snail shell observed in Ladder Creek clays. It is surprising that potters did not crush all of the snail shell when processing the clay, but its survival here provides a very good marker of local clay use.

\subsection{Ledbetter Red slip color and surface treatment}

Gunnerson's initial observations of Ledbetter Red from 14SC304 suggest that these locally made red-slipped ceramics should be much less well polished and have greater variation in slip color than Tewa Red from the H. P. Mera collections. This is true of many examples of Ledbetter Red (Figure 3), but Gunnerson's generalizations obscure important variation between sites.

Potters at the different sites had different levels of success in duplicating the red color of Tewa Red, with the closest and most consistent color match at 14SC409. The most common slip color at 14SC1 is reddish brown (Table 1). At 14SC304 the most common color is yellowish red, 
but there are more cases of "red" slips than at 14SC1 (Table 2). Interior slips are usually red at 14SC409, with exterior slips tending toward browner and more variable colors (Table 3). Other variation between sites includes the presence of smudged and polished interiors only at $14 \mathrm{SC} 1$, and the use of a thin wash on vessel exteriors at 14SC304 and 14SC409 instead of a thicker slip (Table 4). Vessel surfaces are well polished at 14SC1. At 14SC304 and 14SC409, slips tend to be poorly polished to smoothed; even when the surface is glossy, there are often pronounced bumps beneath the polish.

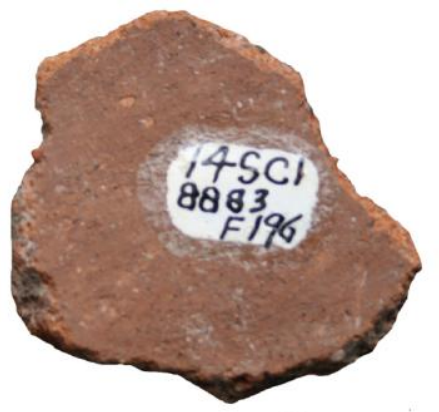

a

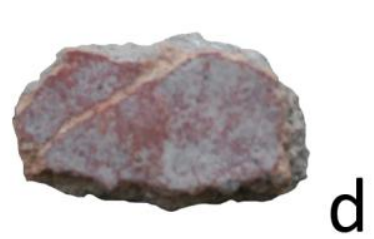

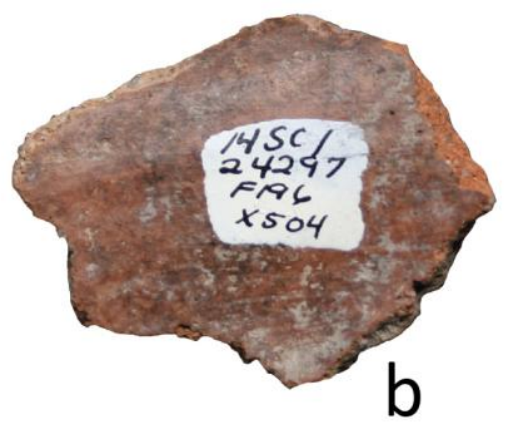

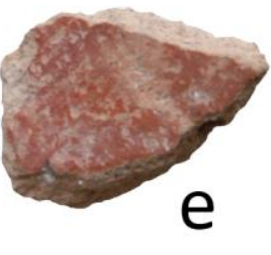

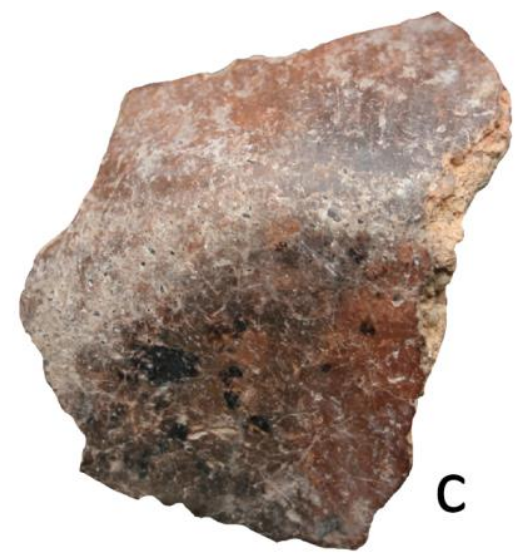

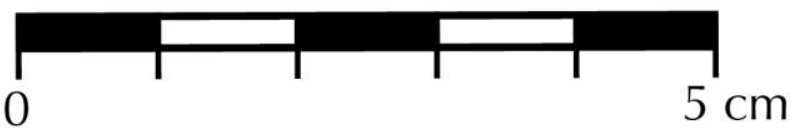

Figure 3. Examples of Ledbetter Red sherds: (a) 14SC1 bowl interior (cat 8883); (b) 14SC1 bowl interior (cat 24297); (c) 14SC1 flat vessel base exterior (cat 12354); (d) 14SC304 bowl exterior (spec 315); (e) 14SC304 bowl interior (spec 316).

\subsection{Oxidation analysis results: paste color, slip attributes, and firing conditions}

The oxidation data are consistent with a local provenance for Ledbetter Red. The oxidized paste colors of the Ledbetter Red samples (Table 5) range from red to light red to "buff" colors, similar to the range observed in the oxidized Dismal River Gray Ware sample (Table 6): red, yellowish 
red, and "buff" (reddish yellow, 7.5YR 7/6). In constrast, all of the samples with sandstone/sand inclusions had oxidized paste colors of red or light red. Although the pastes of Ledbetter Red and Dismal River Gray Ware ceramics oxidize to the same color range, there is a greater proportion of brown and black colors in Dismal River Gray Ware pastes prior to refiring. (Gray pastes are present on Ledbetter Red ceramics only alongside smudged and polished interiors.) This indicates that Ledbetter Red ceramics were fired in a more oxidizing atmosphere, which was important for developing the red color of the slip.

The buff paste colors, which are more common here than in an oxidized sample of Central Plains ceramics (Roper et al. 2010), overlap with the range of paste colors seen in Tewa ceramic pastes in the H. P. Mera Collection. Lest paste color be used as a marker for Tewa manufacture, it is important to recognize that buff paste colors are also possible with western Kansas clays fired in an oxidizing atmosphere. The only reliable guide to identifying ceramics from the Española Basin area is to identify the characteristic ash/pumice/tuff temper in the paste.

The oxidation analysis revealed that at $14 \mathrm{SC} 1$ the smudged interior surfaces had been slipped prior to smudging (e.g., cat 6742 in Tables 1, 5), as done for Tewa black polished types (Guthe 1925; Mera 1939). It also revealed that the differences in slip color between Ledbetter Red from 14SC1 and Tewa Red are due primarily to firing conditions rather than the qualities of the slip raw material. Refiring changes reddish brown and brown slips to red and weak red colors, which are much more consistent with the original (unrefired) colors of Tewa Red slips.

Twentieth-century Tewa potters ensured bright red slips during firing by keeping fuel away from vessels and removing vessels while hot; in contrast, black surfaces were produced by instead leaving the vessels in place and smothering the fire with manure (Guthe 1925; LeFree 1975). When firing red-slipped vessels, potters at Santa Clara in 1968 (LeFree 1975) used tin 
cans, corrugated tin, and a metal grill to raise pots off the ground and to keep fuel from touching or falling on the pottery. This improvised kiln was then surrounded by bark slabs, either gathered cottonwood bark or obtained from a lumber mill. Once the fire died down, roughly 30 minutes after lighting it, potters removed hot vessels with a pole. Vessels went from brown to red as they cooled. The process was similar for polished black vessels at Santa Clara, except that cow dung was added as fuel to the bark and then the fire was smothered with fine manure once it reached maximum temperature. Vessels were then left in the kiln for another 30 minutes or longer. Potters at San Ildefonso in 1921 apparently used dung for firing all types; they too removed red slipped and polychrome vessels while hot, but smothered the fire with manure for black polished vessels (Guthe 1925).

Dismal River potters probably used bison dung as fuel, which was plentiful where bison were hunted and may even have been traded by some Plains groups to Puebloan potters for vessel firing (Schroeder 1972; Snow 1982). Animal dung is also used widely for firing where domestic animals are present, including in the postcontact Pueblos after livestock was introduced (Shepard 1985). Dung is a good insulator of heat but burns quickly, more so than other fuels (Shepard 1985). Dismal River potters probably left vessels to cool where they were fired, rather than removing hot vessels, which would have oxidized carbon from the hot vessel surface in the open air.

In summary, different firing procedures must have been used to produce Ledbetter Red and Dismal River Gray Ware. Although potters at 14SC1 oxidized the surfaces of Ledbetter Red vessels, they did not successfully replicate bright red Tewa slips. This is due to incomplete oxidation of the slip, rather than the color of the slip material. Did these Ledbetter Red pots cool a little too much before being removed from the fire? If firing materials or conditions at the site 
differed from those to which Puebloan potters were accustomed, they may have misjudged the rate of cooling and pulled vessels out too late. At any rate, these technical problems were solved at the later sites 14SC304 and 14SC409, where the red slips on Ledbetter Red ceramics are often more similar in color to those on Tewa Red ceramics.

\subsection{Ledbetter Red vessel forms}

The surface treatments on sherds with both surfaces visible indicate that all are bowls (see Table 4). Bowls are a common form for Tewa Red vessels, but rare in Dismal River sites outside the study area (Beck and Trabert 2014; Trabert 2015). Most of the 15 rim sherds in the sample are very small, providing little additional information on vessel form. Two rim sherds (Figure 4) and two base sherds (Figures 5-6) suggest that soup plates and direct rim bowls were present in the study area. Soup plates are a common form for red-slipped unpainted ceramics after Spanish colonization (Warren 1977).
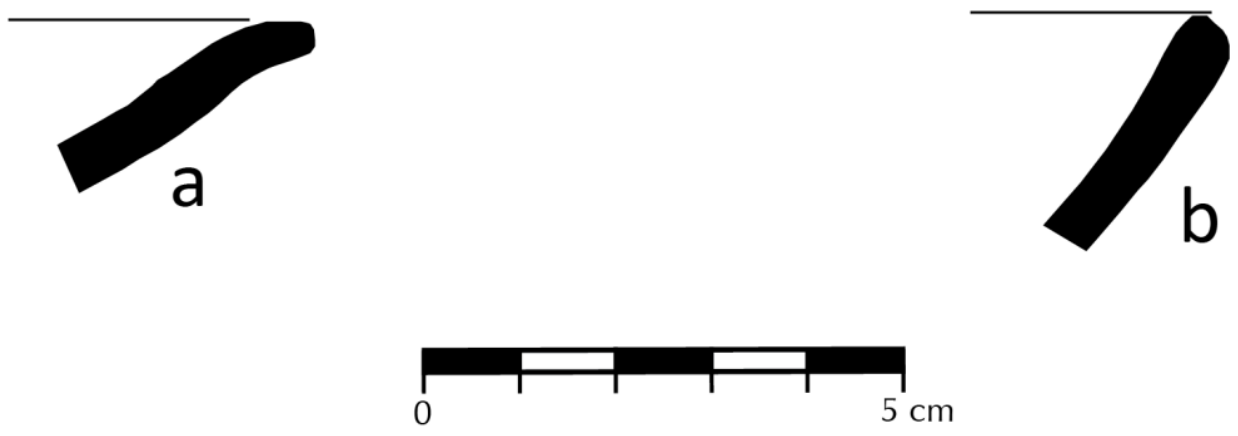

Figure 4. Rim sherd profiles from (a) 14SC1 (SC-22, cat 24115; see also Figure 2c) and (b) 14SC409 (cat 46-3). 
Very flat bases similar to the flat base at 14SC1 appear on "plain rimmed" Plain Red bowls from Pecos (Kidder 1936:Figure 247f, g). Heights of these examples are 88-98 percent of the vessel base diameter, and the orifice is 230 percent of the vessel base diameter in both cases. If the 14SC1 bowl (Figure 5), which had a $5 \mathrm{~cm}$ base diameter, had a similar direct rim vessel form, it might have been 4.4-4.9 $\mathrm{cm}$ tall with an orifice of $11.5 \mathrm{~cm}$. Flat bases also appear on soup plates, such as this example from seventeenth-century contexts at the Palace of the Governors in Santa Fe (Figure 6; C. Dean Wilson, personal communication, 2015).

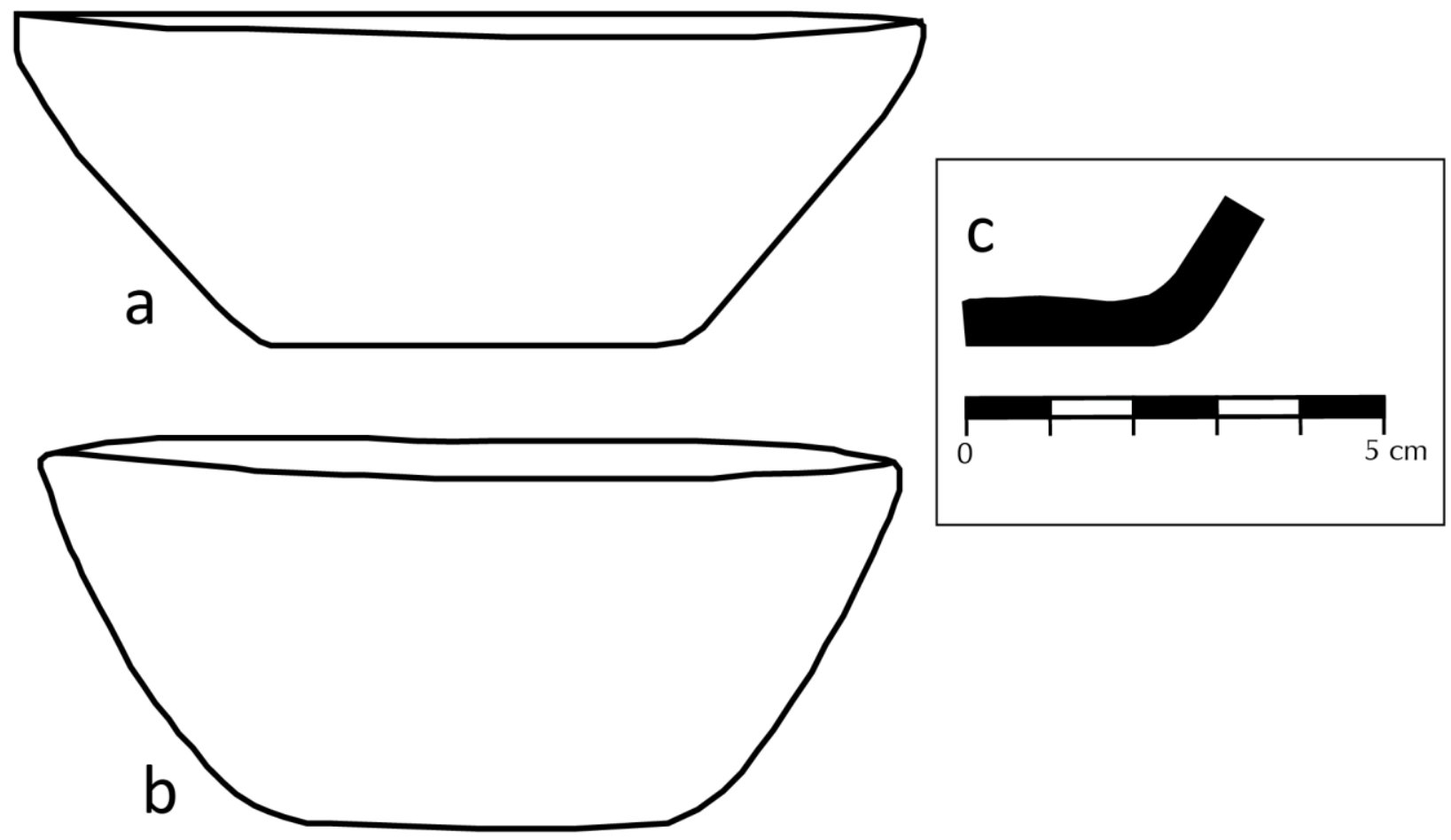

Figure 5. Vessel shape comparison between (a) and (a-b) Plain Red vessels from Pecos (redrawn from Kidder 1936:Figure 247f, g) and (c) base sherd from 14SC1 (cat 12354; see also Figure 3c). 

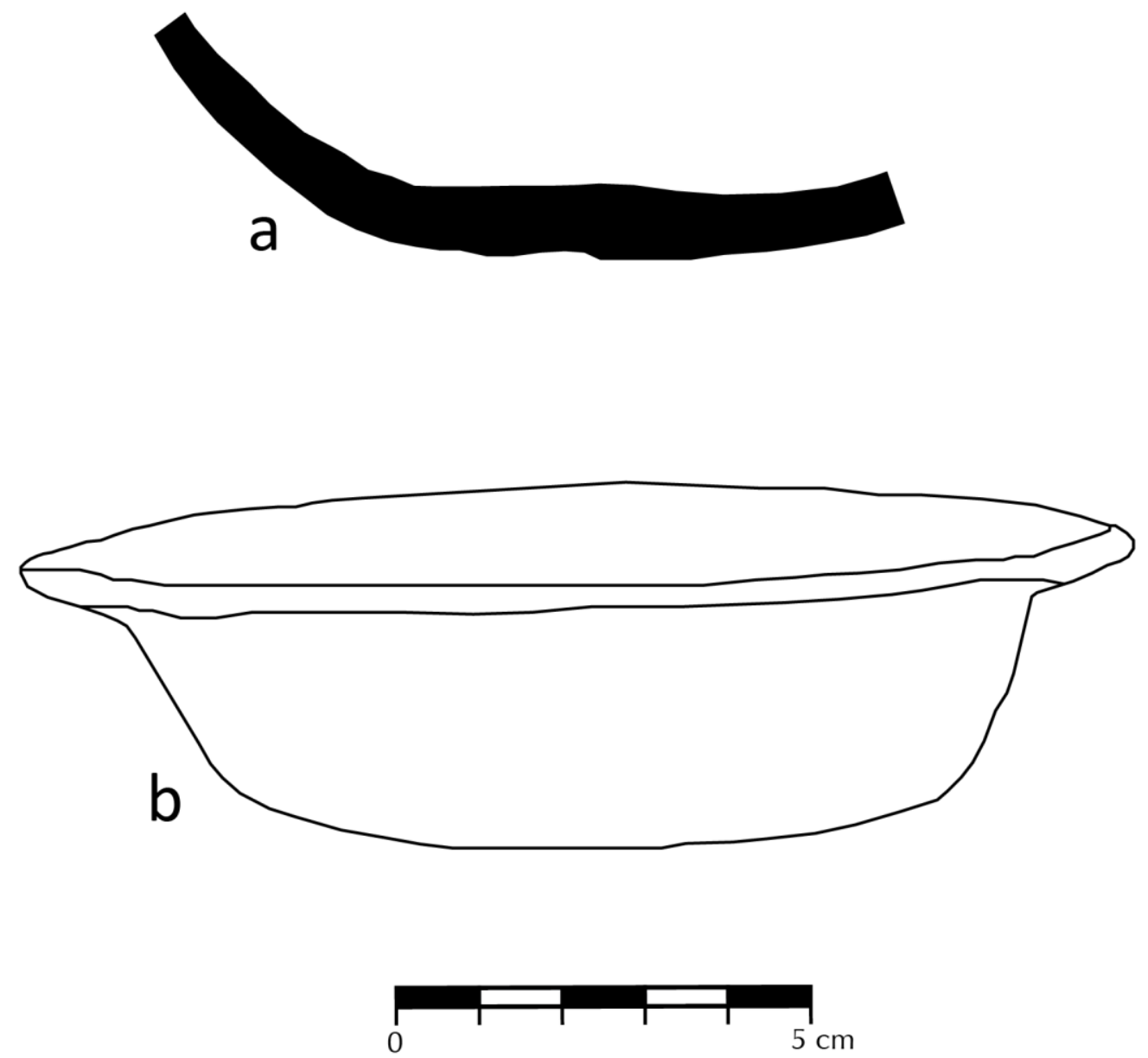

Figure 6. Vessel shape comparison between (a) base sherd from 14SC409 (cat 90) and (b) soup plate from Palace of the Governors (C. Dean Wilson, personal communication, 2015).

\section{Conclusion}

The type Ledbetter Red represents red-slipped unpainted ceramics produced in western Kansas. Although these ceramics were made with locally available materials, including sand from the nearby Ogallala Formation, they differ technologically from local Dismal River Gray Ware, not only in the application of a red slip but also in the firing atmosphere and in the use of polishing and smudging. Ledbetter Red ceramics were well oxidized, unlike the reducing atmosphere used for firing Dismal River Gray Ware. Surfaces were polished with visible 
polishing striations and bowl interiors were occasionally smudged, with surfaces slipped prior to smudging. These attributes are consistent with the type Tewa Red, produced by Tewa potters and imitators after A.D. 1600.

Potters in the Tewa Basin were better able to achieve a bright red slip than those in western Kansas, seemingly due to better control over firing conditions. Potters at the earliest site, 14SC1, had the most difficulty in replicating the bright red Tewa slip color. If these potters had recently moved here from the northern Rio Grande region, as argued by Beck and Trabert (2014), they may have been adjusting to local differences in firing materials or conditions. At the two later sites, 14SC304 and 14SC409, the Ledbetter Red slips are often a better match to Tewa Red slips. Other attributes also change through time, however; slips are thinner at the later two sites and the quality of polishing declines. In these respects, Ledbetter Red became less like Tewa Red over time.

We interpret the earliest site (14SC1) as the entry of Puebloan potters into our study area at least during the period AD 1650-1700 if not earlier. We can only identify them as coming from the northern Rio Grande area, as there are several possible communities of origin (Beck and Trabert 2014; Trabert 2015). The ceramics made by these potters after arriving in western Kansas include a local version of Tewa Red known as Ledbetter Red. Although they used local raw materials, they otherwise conformed to the conventions for Tewa Red, including slip thickness, polishing, and smudging. They clearly used a different vessel firing process than that used by local ancestral Apache potters, necessary for oxidizing the red slip. In this early period, however, the new arrivals still needed to learn the nuances of working with local fuel sources and firing conditions. 
Ledbetter Red was made later at 14SC304 and 14SC409, possibly decades later by the descendants of the Puebloan women at 14SC1. These potters lived a primarily Athabaskan lifestyle, judging from the architecture and other material culture, and may represent the full integration of people of Puebloan origin into the local population. They successfully produced a bright red slip on Ledbetter Red, having apparently worked out any kinks in the firing process. Other "Puebloan" aspects of ceramic manufacture are deemphasized, however; interior smudging was abandoned, and polishing became more faint and careless. The potters who made Ledbetter Red at 14SC304 and 14SC409 were surrounded by potters working in a different ceramic tradition, and lacked the training or the inclination to maintain these earlier traits of Tewa Red. The highly visible red was still important, however, and may have been a significant marker of heritage and identity for those descended from the original Puebloan potters.

\section{Acknowledgments}

Financial support for this project was provided by the College of Liberal Arts and Sciences at the University of Iowa to Margaret Beck and Matthew Hill, a National Science Foundation Dissertation Improvement Grant (\# 1316758) to Margaret Beck and Sarah Trabert, and a University of Iowa Social Science Funding Program grant to Matthew E. Hill. Our work has also benefitted from the assistance and engagement of the Kansas Historical Society (especially Bob Hoard, Chris Garst, and Anita Frank) and Lake Scott State Park (especially Greg Mills and Rick Stevens). All of these people have been of tremendous help in our work with the Scott County sites and collections. Dody Fugate at the Museum of Indian Arts and Culture Laboratory of Anthropology in Santa Fe provided invaluable access to and information on the ceramic type 
collections in the H. P. Mera Room. We also greatly appreciate interest and feedback from Mary Adair, Bill Billeck, C. Dean Wilson, Jim Wilson, and the numerous students and volunteers who have been involved in this project. 


\section{REFERENCES CITED}

Batkin, Jonathan

1987 Pottery of the Pueblos of New Mexico, 1700-1940. The Taylor Museum of the Colorado Springs Fine Arts Center, Colorado Springs, Colorado.

Baugh, Timothy, G. and Frank W. Eddy

1987 Rethinking Apachean Ceramics: The 1985 Southern Athapaskan Ceramics Conference. American Antiquity 52(4): 793-798.

Beck, Margaret E.

2006 Linking Finished Ceramics to Raw Materials: Oxidized Color Groups for Lowland Desert Clays. Kiva: The Journal of Southwestern Anthropology and History 72(1):93118.

Beck, Margaret E., Jill Onken, B. Sunday Eiselt, J. Andrew Darling, and Jeff Ferguson 2012 Geomorphological Setting of Buff-firing Pottery Clays in the Lower Gila Valley, Southwestern Arizona. Journal of Archaeological Science 39:321-331.

Beck, Margaret E., and Sarah Trabert

2014 Kansas and the Post-Revolt Puebloan Diaspora: Ceramic Evidence from the Scott County Pueblo. American Antiquity 79(2):314-336.

Blakeslee, Donald J., and Marlin F. Hawley

2006 The Great Bend Aspect. In Kansas Archaeology, edited by Robert J. Hoard and William E. Banks, pp. 165-179. University Press of Kansas, Lawrence.

Brooks, James F.

2002 Captives and Cousins: Slavery, Kinship, and Community in the Southwest Borderlands. The University of North Carolina Press, Chapel Hill.

Brunswig, Robert H., Jr.

1995 Apachean Ceramics in Eastern Colorado: Current Data and New Directions. In Archaeological Pottery of Colorado: Ceramic Clues to the Prehistoric and Protohistoric Lives of the State's Native Peoples, edited by Robert H. Brunswig, Jr., Bruce Bradley, and Susan M. Chandler, pp. 172-207. CCPA Occasional Papers No. 2. Colorado Council of Professional Archaeologists, Denver.

Dick, Herbert W., Daniel Wolfman, Curtis Schaafsma, and Michael A. Adler

1999 Prehistoric and Early Historic Architecture and Ceramics at Picuris. In Picuris Pueblo Through Time: Eight Centuries of Change at a Northern Rio Grande Pueblo, edited by Michael A. Adler and Herbert W. Dick, pp. 43-99. William P. Clements Center for Southwest Studies, Southern Methodist University. 
Diffendal, Robert F.

1984 Comments on the Geologic History of the Ogallala Formation in the Southern Panhandle of Nebraska Proceedings of the Ogallala Aquifer Symposium II, edited by George A. Whetstone, pp. 194-215. Papers in Natural Resources. Paper 116.University of Nebraska, Lincoln.

Dozier, Edward

1954 The Hopi-Tewa of Arizona. University of California Publications in American Archaeology and Ethnology. University of California, Berkeley.

Elllis, Florence H.

1964 Archaeological History of Nambe Pueblo, $14^{\text {th }}$ Century to the Present. American Antiquity 30(1):34-42.

Ferg, Alan

1984 Historic Archaeology on the San Antonio de las Huertas Grant, Sandoval County New Mexico. CASA Papers No.3, Complete Archaeological Service Associates, Cortez.

Ferguson, T. J. and Robert W. Preucel

2005 Signs of the Ancestors: An archaeology of the Mesa Villages of the Pueblo Revolt. In Structure and Meaning in Human Settlement, edited by Joseph Rykwert and Tony Atkin, pp. 185-207. University Museum Press, Philadelphia.

Forbes, Jack D.

1994 Apache, Navaho, and Spaniard, second edition. University of Oklahoma Press, Norman, Oklahoma.

Frank, Larry, and Francis H. Harlow

1990 Historic Pottery of the Pueblo Indians, 1600-1880. Schiffer Publishing Company, West Chester, Pennsylvania.

Galusha, T. and J. C. Blick

1971 Stratigraphy of the Santa Fe Group, New Mexico. American Museum of Natural History, Bulletin 144, Part 1, pp. 7-127. Washington D.C.

Gunnerson, James H.

1968 Plains Apache Archaeology: A Review. Plains Anthropologist 13(41): 167-189

1987 Archaeology of the High Plains. Cultural Resource Series No. 19. Bureau of Land Management, Denver, Colorado.

1992 Protohistoric Apaches in Northeastern New Mexico. In Cultural Encounters and Episodic Droughts: The Protohistoric Period on the Southern Plains, edited by Eileen Johnson, pp. 91-102. Lubbock Lake Landmark Quaternary Research Center Series Number 3. Museum of Texas Tech University, Lubbock, Texas. 
1998 From the Plains and Back Again. The Kansas Anthropologist 19:37-61.

2006 Archaeological Reminiscences: From the Plains and Back Again. Plains Anthropologist 51(200):615-632.

Guthe, Carl E.

1925 Pueblo Pottery Making: A Study at the Village of San Ildefonso. Published for the Department of Archaeology, Phillips Academy, Andover, Massachusetts. Yale University Press, New Haven.

Habicht-Mauche, Judith A.

1987 Southwestern-Style Culinary Ceramics on the Southern Plains: A Case Study of Technological Innovation and Cross-Cultural Interaction. Plains Anthropologist 32:175189.

1993 The Pottery from Arroyo Hondo Pueblo, New Mexico.: Tribalization in the Northern Rio Grande. Arroyo Hondo Archaeological Series Volume 8. School of American Research Press, Santa Fe.

2000 Pottery, Food, Hides, and Women: Labor, Production, and Exchange Across the Protohistoric Plains-Pueblo Frontier. In The Archaeology of Regional Interaction: Religion, Warfare, and Exchange Across the American Southwest and Beyond, edited by Michelle Hegmon, pp. 209-231. University Press of Colorado, Boulder.

2008 Captive Wives? The Role and Status of Nonlocal Women on the Protohistoric Southern High Plains. In Invisible Citizens: Captives and Their Consequences, edited by Catherine M. Cameron, pp. 181-204. The University of Utah Press, Salt Lake City.

Harlow, Francis H.

1973 Matte-Paint Pottery of the Tewa, Keres and Zuni Pueblos. Museum of New Mexico, Santa Fe.

Hill, Matthew E., Jr., Margaret E., Sarah J. Trabert, and Mary Adair

n.d. A Hard Time to Date: The Occupational History of Scott County Pueblo (14SC1) and the Presence of Puebloan Populations on the High Plains. In preparation.

Hoard, Robert J.

2009 Archaeological Survey of Scott State Park: 2009 Kansas Archeology Training Program Field School. The Kansas Anthropologist 30:41-133.

Kidder, A. V.

1936 The Pottery of Pecos, Volume II, Part I: The Glaze-Paint, Culinary, and Other Wares. Papers of the Southwestern Expedition, Phillips Academy, Andover (Department of Archeology). Yale University Press, New Haven. 
LeFree, Betty

1975 Santa Clara Pottery Today. A School of American Research Book. University of New Mexico Press, Albuquerque.

Levine, Daisy F.

2004 Native Ceramics Analysis and Interpretation. In Adaptations on the Anasazi and Spanish Frontiers: Excavations at Five Sites near Abiquiu, Rio Arriba County, New Mexico , by James L, Moore, Jeffrey L. Boyer, and Daisy F. Levine. Museum of New Mexico, Laboratory of Anthropology, Archaeology Notes 187 pp. 147-168, Santa Fe.

Mandel, Rolfe D.

2007 Geomorphology and Stratigraphy. In Results of Evaluative Testing at Site 14SC112 in the Ladder Creek Drainage, Scott County, Kansas (Addendum 16 to: Cheyenne Plains Gas Pipeline Company Cheyenne Plains 226A-30” Pipeline: Cultural Resource Inventory and Test Excavations) by Jennifer Borresen Lee and Damita Hiemsta, pp. 8-31. Prepared by Metcalf Archaeological Consultants, Inc., Eagle, CO for Cheyenne Plains Gas Pipeline Company, Colorado Springs, CO.

Matthew, A.J., A.J. Woods, and C. Oliver

1991 Spots Before the Eyes: New Comparison Charts for Visual Percentage Estimation in Archaeological Material. In Recent Developments in Ceramics Petrology, edited by Andrew Middleton and Ian Freestone, pp. 211-264. British Museum Occasional Paper No. 81. British Museum Research Laboratory, London.

Mera, H. P.

1939 Style Trends of Pueblo Pottery in the Rio Grande and Little Colorado Cultural Areas from the Sixteenth to the Nineteenth Century. Memoirs of the Laboratory of Anthropology Volume III. Santa Fe, New Mexico.

Preucel, Robert W.

2002 Writing the Pueblo Revolt. In Archaeologies of the Pueblo Revolt: Identity, Meaning, and Renewal in the Pueblo World, edited by Robert W. Preucel, pp. 3-29. University of New Mexico Press, Albuquerque, New Mexico.

Roper, Donna C., Richard L. Josephs, and Margaret E. Beck

2010 Determining Provenance of Shell-tempered Pottery from the Central Plains using Petrography and Oxidation Analysis. American Antiquity 75(1):134-157.

Schaafsma, Curtis

2002 Apaches De Navajo: Seventeenth-Century Navajos in the Chama Valley of New Mexico. The University of New Mexico Press, Salt Lake City.

Schroeder, Albert H.

1972 Rio Grande Ethnohistory. In New Perspectives on the Pueblos, edited by Alfonso Ortiz. University of New Mexico Press, Albuquerque. 
1974 A Study of the Apache Indians, Parts I, II, and III. Garland Publishing, Inc., New York.

Shepard, Anna O.

1936 The Pottery of Pecos, Volume II, Part II: The Technology of Pecos Pottery. Papers of the Southwestern Expedition, Phillips Academy, Andover (Department of Archeology). Yale University Press, New Haven.

1942 Rio Grande Glaze Paint Ware: A Study Illustrating the Place of Ceramic Technological Analysis in Archaeological Research. Contributions to American Anthropology and History No. 39. Publication 528. Carnegie Institution of Washington, Washington, D. C.

1985 Ceramics for the Archaeologist. Publication 609. Carnegie Institution of Washington, Washington, D. C. Reprinted by Braun-Brumfield, Inc., Ann Arbor, Michigan.

Snow, David

1982 The Rio Grande Glaze, Matte-Paint, and Plainware Tradition. In Southwestern Ceramics: A Comparative Review, edited by Albert Schroeder. Arizona Archaeologist 15, edited A. H. Schroeder, pp. 235-278. Arizona Archaeological Society, Phoenix.

Spielmann, Katherine A.

1983 Late Prehistoric Exchange Between the Southwest and Southern Plains. Plains Anthropologist 28:257-272.

Spielmann, Katherine A. (editor)

1991 Farmers, Hunters, and Colonists: Inteaction between the Southwest and Southern Plains. University of Arizona Press, Tucson.

Spicer, Edward H.

1962 Cycles of Conquest: The Impact of Spain, Mexico, and the United States on Indians of the Southwest. University of Arizona Press, Tucson.

Terry, R.D., and V.G. Chilingar

1955 Summary of "Concerning Some Additional Aids in Studying Sedimentary Formations" by M.S. Shvestov. Journal of Sedimentary Petrology 25(5):229-234.

Trabert, Sarah

2015 Plural Communities on the Plains: Dismal River People and the Puebloan Diaspora. Unpublished Ph.D. dissertation submitted to the Department of Anthropology, University of Iowa, Iowa City.

Trabert, Sarah, and Matthew E. Hill

n.d. A Discussion of Dismal River Mortuary Practices and Implications for Cultural Affiliation. Paper to be submitted to Plains Anthropologist. In preparation. 
Trabert, Sarah, David Hill, Sunday Eiselt, Jeffrey Ferguson, and Margaret Beck

2015 Following a Glittering Trail: A Characterization Analysis of Micaceous sherds Recovered from Dismal River Sites. Paper submitted to American Antiquity; in review.

Vint, James M.

1999 Ceramic Artifacts. In The Bandelier Archaeological Survey: Volume II, edited by Robert P. Powers and Janet D. Orcutt, pp. 389-467. Intermountain Cultural Resources Management Professional Paper No. 57. National Park Service, Department of the Interior.

Warren, A. Helene

1976 The Pottery of Pueblo del Encierro. In The Ceramics and Mineral Resources of LA 70 and the Cochiti Area, by A. H. Warren. Section B In Archaeological Excavations at Pueblo del Encierro, LA 70 Cochiti Dam Salvage Project, Cochiti, New Mexico Final Report: 1964-1965 Field Seasons, assembled and edited by David H. Snow. Museum of New Mexico, Laboratory of Anthropology Notes 78, Santa Fe.

1977 Appendix I: New Dimensions in the Study of Prehistoric Pottery. In Archaeological Investigations in Cochiti Reservoir, New Mexico, Volume 2: Excavation and Analysis, 1975 Season, edited by R. C. Chapman and J. V. Biella, pp. 362-374. Office of Contract Archaeology, University of New Mexico, Albuquerque.

Wedel, Waldo R.

1949 Some Central Plains Sherd Types from Kansas. In Proceedings of the Fifth Plains Conference for Archeology, assembled by John L. Champe, pp. 86-90. Note Book No. 1. Laboratory of Anthropology, University of Nebraska, Lincoln.

1959 An Introduction to Kansas Archaeology. Bureau of American Ethnology Bulletin 174. Smithsonian Institution, Washington, D.C.

Wilson, C. Dean

2011 Historic Indigenous Ceramic Types. In Settlers and Soliders: The Historic Component at El Pueblo de Santa Fe (LA 1051), by Stephen C. Lentz and Matthew J. Barbour, pp. 223233. Archaeology Notes 410. New Mexico Office of Archaeological Studies, Santa Fe.

Wilson, Gordon P.

2010 The Ceramics of the Northern Rio Grande Valley and Galisteo Basin to AD 1700. Santa Fe, New Mexico. 
Table 1. Ledbetter Red ceramics from 14SC1.

\begin{tabular}{|c|c|c|c|c|c|c|c|c|}
\hline CAT NO & $\#$ & SIZE & $\begin{array}{l}\text { Petro. } \\
\text { sample } \\
\text { no. }\end{array}$ & $\begin{array}{l}\text { Exterior } \\
\text { (original) }\end{array}$ & $\begin{array}{c}\text { Exterior } \\
\text { (original) } \\
\text { color }\end{array}$ & $\begin{array}{l}\text { Interior } \\
\text { (original) }\end{array}$ & $\begin{array}{c}\text { Interior } \\
\text { (original) } \\
\text { color }\end{array}$ & Surface \\
\hline \multicolumn{9}{|l|}{ rim } \\
\hline 1130 & 1 & 1 & & 10R $3 / 6$ & dark red & $\begin{array}{c}\text { obscured by } \\
\text { caliche }\end{array}$ & ND & $\begin{array}{l}\text { slip int } \\
\text { and ext }\end{array}$ \\
\hline 3518 & 1 & 1 & & 5YR 5/4 & $\begin{array}{c}\text { reddish } \\
\text { brown }\end{array}$ & $5 Y R 4 / 6$ & $\begin{array}{c}\text { yellowish } \\
\text { red }\end{array}$ & $\begin{array}{l}\text { slip int } \\
\text { and ext }\end{array}$ \\
\hline 4607 & 1 & 1 & & $10 \mathrm{R} 4 / 4$ & red & 2.5YR 5/4 & $\begin{array}{c}\text { reddish } \\
\text { brown }\end{array}$ & $\begin{array}{l}\text { slip int } \\
\text { and ext }\end{array}$ \\
\hline 7489 & 1 & 1 & & $\begin{array}{l}\text { blackened with } \\
\text { carbon }\end{array}$ & ND & 7.5YR 4/4 & brown & $\begin{array}{l}\text { slip int } \\
\text { only }\end{array}$ \\
\hline 24115 & 1 & 2 & SC-22 & ND & ND & ND & ND & $\begin{array}{l}\text { slip int } \\
\text { and ext }\end{array}$ \\
\hline 24769 & 1 & 1 & & $5 \mathrm{YR} 4 / 4$ & $\begin{array}{l}\text { reddish } \\
\text { brown }\end{array}$ & $7.5 \mathrm{YR} 4 / 3$ & brown & $\begin{array}{l}\text { slip int } \\
\text { and ext }\end{array}$ \\
\hline body & & & & & & & & \\
\hline 4597 & 1 & 1 & & slip 10R 4/4 & weak red & $\begin{array}{c}\text { slip } 2.5 \mathrm{YR} \\
4 / 4 \\
\end{array}$ & $\begin{array}{c}\text { reddish } \\
\text { brown }\end{array}$ & $\begin{array}{l}\text { slip int } \\
\text { and ext }\end{array}$ \\
\hline 4606 & 1 & 1 & & $\begin{array}{c}\text { slip } 10 \mathrm{R} 5 / 8 \text { to } \\
2.5 \mathrm{YR} 3 / 3\end{array}$ & red & $\begin{array}{c}\text { black } \\
\text { polished }\end{array}$ & NA & $\begin{array}{c}\text { int } \\
\text { smudged } \\
\text { and } \\
\text { polished; } \\
\text { slip ext }\end{array}$ \\
\hline 6742 & 1 & 1 & & slip 10R 5/4 & weak red & $\begin{array}{l}\text { dark brown } \\
\text { polished }\end{array}$ & NA & $\begin{array}{c}\text { int } \\
\text { smudged } \\
\text { and } \\
\text { polished; } \\
\text { slip ext }\end{array}$ \\
\hline 8883 & 1 & 2 & & unslipped & $\mathrm{NA}$ & slip 5YR 4/4 & $\begin{array}{c}\text { reddish } \\
\text { brown }\end{array}$ & $\begin{array}{c}\text { slip int } \\
\text { only }\end{array}$ \\
\hline 9904 & 1 & 2 & & $\begin{array}{c}\text { slip 5YR 5/6 to } \\
\text { 10R 4/4 }\end{array}$ & weak red & slip 5YR 5/3 & $\begin{array}{l}\text { reddish } \\
\text { brown }\end{array}$ & $\begin{array}{l}\text { slip int } \\
\text { and ext }\end{array}$ \\
\hline 10182 & 2 & 1 & & slip 10YR 4/6 & $\begin{array}{c}\text { dark } \\
\text { yellowish } \\
\text { brown } \\
\end{array}$ & not visible & ND & $\begin{array}{l}\text { int not } \\
\text { visible; } \\
\text { slip ext }\end{array}$ \\
\hline 11273 & 1 & 1 & SC-51 & ND & ND & ND & ND & $\begin{array}{l}\text { slip int } \\
\text { and ext }\end{array}$ \\
\hline 12347 & 1 & 1 & & slip 2.5YR 4/4 & $\begin{array}{l}\text { reddish } \\
\text { brown }\end{array}$ & $\begin{array}{c}\text { slip } 2.5 \mathrm{YR} \\
4 / 4\end{array}$ & $\begin{array}{l}\text { reddish } \\
\text { brown }\end{array}$ & $\begin{array}{l}\text { slip int } \\
\text { and ext }\end{array}$ \\
\hline 12414 & 1 & 1 & & slip $2.5 \mathrm{YR} 4 / 6$ & red & $\begin{array}{c}\text { slip } 2.5 \mathrm{YR} \\
4 / 6\end{array}$ & red & $\begin{array}{l}\text { slip int } \\
\text { and ext }\end{array}$ \\
\hline 12416 & 1 & 1 & & slip 2.5YR 5/4 & $\begin{array}{l}\text { reddish } \\
\text { brown }\end{array}$ & $\begin{array}{c}\text { slip 2.5YR } \\
5 / 6\end{array}$ & red & $\begin{array}{l}\text { slip int } \\
\text { and ext }\end{array}$ \\
\hline 13153 & 1 & 1 & & slip 2.5YR 4/4 & $\begin{array}{l}\text { reddish } \\
\text { brown }\end{array}$ & slip 5YR 5/4 & $\begin{array}{l}\text { reddish } \\
\text { brown }\end{array}$ & $\begin{array}{l}\text { slip int } \\
\text { and ext }\end{array}$ \\
\hline 13154 & 1 & 1 & & $\begin{array}{l}\text { unslipped; } \\
\text { simple } \\
\text { stamped? }\end{array}$ & NA & slip 5YR 5/4 & $\begin{array}{c}\text { reddish } \\
\text { brown }\end{array}$ & $\begin{array}{c}\text { slip int } \\
\text { only }\end{array}$ \\
\hline 21114 & 1 & 1 & & slip 10R 4/6 & red & $\begin{array}{l}\text { dark brown } \\
\text { polished? }\end{array}$ & NA & $\begin{array}{c}\text { int } \\
\text { smudged } \\
\text { and } \\
\text { polished; }\end{array}$ \\
\hline
\end{tabular}




\begin{tabular}{|c|c|c|c|c|c|c|c|}
\hline & & & & & & & slip ext \\
\hline 21259 & 1 & 2 & unslipped & NA & slip 5YR 5/3 & $\begin{array}{l}\text { reddish } \\
\text { brown }\end{array}$ & $\begin{array}{l}\text { slip int } \\
\text { only }\end{array}$ \\
\hline 23523 & 1 & 1 & $\begin{array}{c}\text { slip but too } \\
\text { small }\end{array}$ & ND & not visible & ND & $\begin{array}{c}\text { int absent; } \\
\text { slip ext }\end{array}$ \\
\hline 24297 & 1 & 2 & slip 7.5YR 5/2 & brown & slip 5YR 5/4 & $\begin{array}{l}\text { reddish } \\
\text { brown }\end{array}$ & $\begin{array}{l}\text { slip int } \\
\text { and ext }\end{array}$ \\
\hline 25399 & 1 & 1 & slip 10R 4/4 & weak red & slip 5YR 4/3 & $\begin{array}{l}\text { reddish } \\
\text { brown }\end{array}$ & $\begin{array}{l}\text { slip int } \\
\text { and ext }\end{array}$ \\
\hline 25863 & 1 & 1 & black polished & NA & $\begin{array}{c}\text { slip 7.5YR } \\
5 / 3\end{array}$ & brown & $\begin{array}{l}\text { slip int } \\
\text { only }\end{array}$ \\
\hline 22773-4 & 1 & 1 & $\begin{array}{c}\text { slip 10R } 5 / 4 \text { to } \\
2.5 \mathrm{YR} 4 / 4\end{array}$ & weak red & $\begin{array}{l}\text { brown to } \\
\text { black } \\
\text { polished }\end{array}$ & NA & $\begin{array}{c}\text { int } \\
\text { smudged } \\
\text { and } \\
\text { polished; } \\
\text { slip ext }\end{array}$ \\
\hline \multicolumn{8}{|l|}{ base } \\
\hline 12354 & 1 & 2 & slip 2.5 YR $4 / 3$ & $\begin{array}{l}\text { reddish } \\
\text { brown }\end{array}$ & $\begin{array}{c}\text { slip } 2.5 \mathrm{YR} \\
4 / 3\end{array}$ & $\begin{array}{l}\text { reddish } \\
\text { brown }\end{array}$ & $\begin{array}{l}\text { slip int } \\
\text { and ext }\end{array}$ \\
\hline
\end{tabular}


Table 2. Ledbetter Red ceramics from 14SC304 (*snail shell fragment in paste).

\begin{tabular}{|c|c|c|c|c|c|c|c|c|}
\hline CAT NO & \# & SIZE & $\begin{array}{c}\text { Petro. } \\
\text { sample } \\
\text { no. }\end{array}$ & $\begin{array}{l}\text { Exterior } \\
\text { (original) }\end{array}$ & $\begin{array}{c}\text { Exterior } \\
\text { (original) } \\
\text { color }\end{array}$ & $\begin{array}{l}\text { Interior } \\
\text { (original) }\end{array}$ & $\begin{array}{c}\text { Interior } \\
\text { (original) } \\
\text { color }\end{array}$ & \\
\hline rim & & & & & & & & $\begin{array}{l}\text { slip int } \\
\text { and ext }\end{array}$ \\
\hline 255 & 1 & 1 & & 10R 4/6 & red & 10R 4/6 & red & ND \\
\hline 266 & 1 & 1 & & too small & & too small & & $\begin{array}{l}\text { slip int } \\
\text { and ext }\end{array}$ \\
\hline $292 *$ & 1 & 1 & & $5 \mathrm{YR} 4 / 3$ & $\begin{array}{c}\text { reddish } \\
\text { brown }\end{array}$ & 5YR 5/6 & $\begin{array}{c}\text { yellowish } \\
\text { red }\end{array}$ & $\begin{array}{l}\text { slip int } \\
\text { and ext }\end{array}$ \\
\hline 319 & 1 & 1 & & 5 YR $5 / 3$ & $\begin{array}{l}\text { reddish } \\
\text { brown }\end{array}$ & 5YR 4/6 & $\begin{array}{l}\text { yellowish } \\
\text { red }\end{array}$ & \\
\hline body & & & & & & & & $\begin{array}{l}\text { int absent; } \\
\text { ext slip }\end{array}$ \\
\hline 264 & 1 & 1 & & $10 \mathrm{R} 4 / 6$ & red & surface gone & & $\begin{array}{l}\text { slip int } \\
\text { and ext }\end{array}$ \\
\hline 264 & 2 & 1 & & $10 \mathrm{R} 4 / 6$ & red & $10 \mathrm{R} 4 / 6$ & red & $\begin{array}{l}\text { slip int } \\
\text { and ext }\end{array}$ \\
\hline 264 & 1 & 1 & & 10R 5/4 & weak red & 10R 5/4 & weak red & ND \\
\hline 264 & 3 & 1 & & too small & & too small & & $\begin{array}{l}\text { slip int; } \\
\text { thin wash } \\
\text { ext }\end{array}$ \\
\hline $285^{*}$ & 2 & 1 & & $\begin{array}{c}7.5 \mathrm{YR} 6 / 4 \text { to } \\
2.5 \mathrm{YR} 4 / 6\end{array}$ & $\begin{array}{l}\text { light brown to } \\
\text { red }\end{array}$ & 5YR 5/6 & $\begin{array}{l}\text { yellowish } \\
\text { red }\end{array}$ & ND \\
\hline 293 & 2 & 1 & & too small & & too small & & ND \\
\hline 293 & 2 & 1 & & too small & & too small & & $\begin{array}{l}\text { slip int } \\
\text { only }\end{array}$ \\
\hline 293 & 1 & 1 & & $\begin{array}{l}\text { unslipped } \\
7.5 \text { YR } 5 / 3\end{array}$ & brown & $5 \mathrm{YR} 4 / 4$ & $\begin{array}{l}\text { reddish } \\
\text { brown }\end{array}$ & ND \\
\hline 294 & 1 & 1 & & damaged & & damaged & & $\begin{array}{l}\text { int slip; } \\
\text { ext absent }\end{array}$ \\
\hline 295 & 1 & 1 & & surface gone & & $10 \mathrm{R} 4 / 6$ & red & $\begin{array}{l}\text { slip int; } \\
\text { thin wash } \\
\text { ext }\end{array}$ \\
\hline $299 *$ & 1 & 1 & & 5 YR 6/4 & $\begin{array}{l}\text { light reddish } \\
\text { brown }\end{array}$ & 10R $5 / 6$ & red & $\begin{array}{l}\text { slip int } \\
\text { only }\end{array}$ \\
\hline $299 *$ & 1 & 1 & & $\begin{array}{l}\text { unslipped } \\
7.5 \mathrm{YR} 6 / 4 \\
\end{array}$ & light brown & $10 \mathrm{R} 4 / 8$ & red & $\begin{array}{l}\text { slip int } \\
\text { only }\end{array}$ \\
\hline 300 & 3 & 1 & & $\begin{array}{c}\text { unslipped } \\
7.5 \mathrm{YR} 5 / 3\end{array}$ & brown & $2.5 \mathrm{YR} 4 / 4$ & $\begin{array}{l}\text { reddish } \\
\text { brown }\end{array}$ & $\begin{array}{l}\text { slip int } \\
\text { and ext }\end{array}$ \\
\hline 301 & 1 & 1 & & 10R $4 / 6$ & red & $10 \mathrm{R} 4 / 6$ & red & $\begin{array}{l}\text { slip int; } \\
\text { thin wash } \\
\text { ext }\end{array}$ \\
\hline $314^{*}$ & 7 & 1 & & $5 Y R 6 / 4$ & $\begin{array}{l}\text { light reddish } \\
\text { brown }\end{array}$ & 5YR 5/6 & $\begin{array}{c}\text { yellowish } \\
\text { red }\end{array}$ & $\begin{array}{c}\text { slip int } \\
\text { only }\end{array}$ \\
\hline 314 & 3 & 1 & & $\begin{array}{l}\text { unslipped } \\
7.5 \text { YR } 6 / 4\end{array}$ & light brown & 5YR 5/6 & $\begin{array}{l}\text { yellowish } \\
\text { red }\end{array}$ & $\begin{array}{l}\text { slip int } \\
\text { and ext }\end{array}$ \\
\hline 315 & 1 & 1 & & 10R $4 / 4$ & weak red & 5YR 5/8 & $\begin{array}{l}\text { yellowish } \\
\text { red }\end{array}$ & $\begin{array}{l}\text { slip int } \\
\text { only }\end{array}$ \\
\hline 316 & 1 & 1 & & $\begin{array}{l}\text { unslipped } \\
7.5 Y R 6 / 4\end{array}$ & light brown & $10 \mathrm{R} 4 / 6$ & red & ND \\
\hline 331 & 1 & 1 & & unknown & & unknown & & $\begin{array}{l}\text { slip int } \\
\text { and ext }\end{array}$ \\
\hline
\end{tabular}




\begin{tabular}{|c|c|c|c|c|c|c|c|c|}
\hline 345 & 1 & 1 & & $10 \mathrm{R} 4 / 6$ & red & 2.5 YR $5 / 6$ & red & $\begin{array}{l}\text { slip int } \\
\text { and ext }\end{array}$ \\
\hline 345 & 1 & 1 & & $5 \mathrm{YR} 4 / 2$ & $\begin{array}{l}\text { dark reddish } \\
\text { gray }\end{array}$ & $5 \mathrm{YR} 4 / 3$ & $\begin{array}{l}\text { reddish } \\
\text { brown }\end{array}$ & $\begin{array}{l}\text { slip int } \\
\text { only }\end{array}$ \\
\hline 345 & 1 & 1 & & $\begin{array}{c}\text { unslipped } \\
7.5 \mathrm{YR} 6 / 4\end{array}$ & light brown & 5YR 5/6 & $\begin{array}{c}\text { yellowish } \\
\text { red }\end{array}$ & $\begin{array}{c}\text { slip int } \\
\text { only }\end{array}$ \\
\hline 345 & 1 & 1 & & $\begin{array}{c}\text { unslipped fire } \\
\text { cloud to } 10 \mathrm{YR} \\
6 / 3\end{array}$ & pale brown & $2.5 \mathrm{YR} 5 / 6$ & red & $\begin{array}{l}\text { slip int; } \\
\text { thin wash } \\
\text { ext }\end{array}$ \\
\hline 364 & 1 & 1 & & $\begin{array}{c}7.5 \text { YR } 6 / 3 \text { to } \\
5 \text { YR } 6 / 3\end{array}$ & & 2.5 YR $5 / 6$ & red & $\begin{array}{l}\text { slip int } \\
\text { only }\end{array}$ \\
\hline 364 & 1 & 1 & & $\begin{array}{l}\text { unslipped } \\
7.5 \text { YR } 6 / 3\end{array}$ & light brown & 2.5 YR $5 / 6$ & red & $\begin{array}{l}\text { slip int; } \\
\text { thin wash } \\
\text { ext }\end{array}$ \\
\hline 367 & 1 & 1 & & $\begin{array}{c}10 \mathrm{YR} 6 / 2 \text { to } \\
10 \mathrm{R} 4 / 4\end{array}$ & $\begin{array}{l}\text { pale red to } \\
\text { weak red }\end{array}$ & $10 \mathrm{R} 4 / 6$ & red & ND \\
\hline 376 & 1 & 2 & SC-27 & ND & & ND & & \\
\hline
\end{tabular}


Table 3. Ledbetter Red ceramics from 14SC409.

\begin{tabular}{|c|c|c|c|c|c|c|c|c|}
\hline CAT NO & $\#$ & SIZE & $\begin{array}{l}\text { Petro. } \\
\text { sample } \\
\text { no. }\end{array}$ & $\begin{array}{c}\text { Exterior } \\
\text { (original) }\end{array}$ & $\begin{array}{c}\text { Exterior } \\
\text { (original) } \\
\text { color }\end{array}$ & $\begin{array}{l}\text { Interior } \\
\text { (original) }\end{array}$ & $\begin{array}{c}\text { Interior } \\
\text { (original) } \\
\text { color }\end{array}$ & Surface \\
\hline \multicolumn{9}{|l|}{ rim } \\
\hline $409-6$ & 1 & 1 & & $10 \mathrm{R} 4 / 6$ & red & $10 \mathrm{R} 4 / 6$ & red & $\begin{array}{l}\text { slip int } \\
\text { and ext }\end{array}$ \\
\hline 409-38-1 & 1 & 2 & & $2.5 \mathrm{YR} 4 / 6$ & red & 10R $4 / 8$ & red & $\begin{array}{l}\text { slip int } \\
\text { and ext }\end{array}$ \\
\hline $409-46-2$ & 1 & 1 & & $5 Y R 4 / 4$ & $\begin{array}{l}\text { reddish } \\
\text { brown }\end{array}$ & $10 \mathrm{R} 4 / 8$ & red & $\begin{array}{l}\text { slip int } \\
\text { and ext }\end{array}$ \\
\hline $409-46-3$ & 1 & 2 & & $5 \mathrm{YR} 4 / 4$ & $\begin{array}{c}\text { reddish } \\
\text { brown }\end{array}$ & $10 \mathrm{R} 4 / 8$ & red & $\begin{array}{l}\text { slip int } \\
\text { and ext }\end{array}$ \\
\hline $409-58$ & 1 & 2 & & $\begin{array}{c}10 \mathrm{R} 4 / 8 \text { to } 5 \mathrm{YR} \\
5 / 6 \\
\end{array}$ & $\begin{array}{c}\text { red to } \\
\text { yellowish red }\end{array}$ & $10 \mathrm{R} 4 / 8$ & red & $\begin{array}{l}\text { slip int } \\
\text { and ext }\end{array}$ \\
\hline \multicolumn{9}{|l|}{ body } \\
\hline $409-2$ & 1 & 1 & & $\begin{array}{l}\text { unslipped } \\
7.5 \mathrm{YR} 6 / 3\end{array}$ & light brown & $10 \mathrm{R} 5 / 6$ & red & $\begin{array}{l}\text { slip int } \\
\text { only }\end{array}$ \\
\hline $409-4$ & 1 & 1 & & 5YR 6/4 & $\begin{array}{l}\text { light reddish } \\
\text { brown }\end{array}$ & $10 \mathrm{R} 4 / 6$ & red & $\begin{array}{l}\text { slip int; } \\
\text { thin wash } \\
\text { ext }\end{array}$ \\
\hline $409-6$ & 1 & 1 & & $\begin{array}{l}10 \mathrm{R} 4 / 4 \text { to } \\
2.5 \mathrm{YR} 5 / 4\end{array}$ & $\begin{array}{l}\text { weak red to } \\
\text { reddish } \\
\text { brown }\end{array}$ & $10 \mathrm{R} 4 / 6$ & red & $\begin{array}{l}\text { slip int } \\
\text { and ext }\end{array}$ \\
\hline $409-6$ & 1 & 1 & & 10R $4 / 6$ & red & $10 \mathrm{R} 4 / 6$ & red & $\begin{array}{l}\text { slip int } \\
\text { and ext }\end{array}$ \\
\hline $409-6$ & 1 & 1 & & 10R $4 / 6$ & red & $10 \mathrm{R} 4 / 6$ & red & $\begin{array}{l}\text { slip int } \\
\text { and ext }\end{array}$ \\
\hline $409-6$ & 1 & 2 & & $\begin{array}{l}10 \mathrm{R} 4 / 6 \text { to } \\
2.5 \mathrm{YR} 5 / 4\end{array}$ & $\begin{array}{l}\text { red to reddish } \\
\text { brown }\end{array}$ & $10 \mathrm{R} 4 / 4$ & weak red & $\begin{array}{l}\text { slip int } \\
\text { and ext }\end{array}$ \\
\hline $409-6$ & 1 & 1 & & $10 \mathrm{R} 4 / 8$ & red & $10 \mathrm{R} 4 / 6$ & red & $\begin{array}{l}\text { slip int } \\
\text { and ext }\end{array}$ \\
\hline $409-10$ & 1 & 1 & & ? Not present & & $10 \mathrm{R} 4 / 6$ & red & $\begin{array}{l}\text { slip int; } \\
\text { ext absent }\end{array}$ \\
\hline $409-10$ & 1 & 1 & & $\begin{array}{c}\text { surface worn } \\
\text { away; } 7.5 \mathrm{YR} \\
6 / 4\end{array}$ & light brown & $10 \mathrm{R} 4 / 6$ & red & $\begin{array}{l}\text { slip int; } \\
\text { ext absent }\end{array}$ \\
\hline $409-18$ & 2 & 1 & & $10 \mathrm{R} 4 / 6$ & red & $10 \mathrm{R} 4 / 6$ & red & $\begin{array}{l}\text { slip int } \\
\text { and ext }\end{array}$ \\
\hline $409-23$ & 1 & 1 & & $\begin{array}{c}\text { surface worn } \\
\text { away; 5YR 6/6 }\end{array}$ & $\begin{array}{l}\text { reddish } \\
\text { yellow }\end{array}$ & $10 \mathrm{R} 4 / 6$ & red & $\begin{array}{l}\text { slip int; } \\
\text { ext absent }\end{array}$ \\
\hline $409-34$ & 1 & 2 & & $\begin{array}{l}\text { fire cloud to } \\
2.5 \text { YR } 5 / 6\end{array}$ & $\begin{array}{l}\text { fire cloud to } \\
\text { red }\end{array}$ & $10 \mathrm{R} 4 / 8$ & red & $\begin{array}{l}\text { slip int } \\
\text { and ext }\end{array}$ \\
\hline $409-37$ & 1 & 1 & & 5YR 5/6 & yellowish red & 10R $4 / 8$ & red & $\begin{array}{l}\text { slip int } \\
\text { and ext }\end{array}$ \\
\hline 409-39 & 1 & 1 & & 2.5 YR $4 / 6$ & red & $10 \mathrm{R} 4 / 8$ & red & $\begin{array}{l}\text { slip int } \\
\text { and ext }\end{array}$ \\
\hline $409-40$ & 1 & 1 & & 5YR 5/6 & yellowish red & $10 \mathrm{R} 4 / 8$ & red & $\begin{array}{l}\text { slip int } \\
\text { and ext }\end{array}$ \\
\hline $409-41$ & 1 & 1 & & 10R $4 / 8$ & red & $10 \mathrm{R} 4 / 8$ & red & $\begin{array}{l}\text { slip int } \\
\text { and ext }\end{array}$ \\
\hline $409-42$ & 1 & 1 & & $\begin{array}{c}10 \mathrm{R} 4 / 8 \text { to } 10 \mathrm{R} \\
4 / 4\end{array}$ & $\begin{array}{l}\text { red to weak } \\
\text { red }\end{array}$ & $10 \mathrm{R} 4 / 8$ & red & $\begin{array}{l}\text { slip int } \\
\text { and ext }\end{array}$ \\
\hline $409-43$ & 1 & 1 & & $10 \mathrm{R} 5 / 6$ & red & $10 \mathrm{R} 4 / 8$ & red & slip int \\
\hline
\end{tabular}




\begin{tabular}{|c|c|c|c|c|c|c|c|c|}
\hline & & & & & & & & and ext \\
\hline $409-44$ & 1 & 1 & & $\begin{array}{c}10 \mathrm{R} 4 / 8 \text { to } 5 \mathrm{YR} \\
4 / 6\end{array}$ & $\begin{array}{c}\text { red to } \\
\text { yellowish red }\end{array}$ & 10R $4 / 8$ & red & $\begin{array}{l}\text { slip int } \\
\text { and ext }\end{array}$ \\
\hline $409-45$ & 1 & 1 & & 10R $5 / 4$ & weak red & 10R $4 / 8$ & red & $\begin{array}{l}\text { slip int } \\
\text { and ext }\end{array}$ \\
\hline $409-45$ & 1 & 1 & & $5 \mathrm{YR} 4 / 4$ & $\begin{array}{l}\text { reddish } \\
\text { brown }\end{array}$ & 10R $4 / 8$ & red & $\begin{array}{l}\text { slip int } \\
\text { and ext }\end{array}$ \\
\hline $409-46$ & 10 & 1 & & $\begin{array}{c}10 \mathrm{R} 4 / 8 \text { to } 5 \mathrm{YR} \\
4 / 3\end{array}$ & $\begin{array}{l}\text { red to reddish } \\
\text { brown }\end{array}$ & 10R $4 / 8$ & red & $\begin{array}{l}\text { slip int } \\
\text { and ext }\end{array}$ \\
\hline $409-46$ & 1 & 2 & & $\begin{array}{c}10 \mathrm{R} 4 / 8 \text { to } 5 \mathrm{YR} \\
5 / 6\end{array}$ & $\begin{array}{c}\text { red to } \\
\text { yellowish red }\end{array}$ & 10R $4 / 8$ & red & $\begin{array}{l}\text { slip int } \\
\text { and ext }\end{array}$ \\
\hline $409-46$ & 1 & 1 & & $5 \mathrm{YR} 4 / 3$ & $\begin{array}{c}\text { reddish } \\
\text { brown }\end{array}$ & $\begin{array}{c}10 \mathrm{R} 4 / 8 \text { to } \\
5 \mathrm{YR} 5 / 6\end{array}$ & $\begin{array}{c}\text { red to } \\
\text { yellowish } \\
\text { red } \\
\end{array}$ & $\begin{array}{l}\text { slip int } \\
\text { and ext }\end{array}$ \\
\hline $409-46$ & 1 & 2 & SC-34 & fire cloud & fire cloud & 10R $4 / 8$ & red & $\begin{array}{l}\text { slip int } \\
\text { only }\end{array}$ \\
\hline $409-51$ & 1 & 1 & & $2.5 \mathrm{YR} 5 / 4$ & $\begin{array}{l}\text { reddish } \\
\text { brown }\end{array}$ & 10R 5/6 & red & $\begin{array}{l}\text { slip int } \\
\text { and ext }\end{array}$ \\
\hline $409-62$ & 1 & 1 & & 10R 4/6 & red & 10R 4/8 & red & $\begin{array}{c}\text { slip int; } \\
\text { thin wash } \\
\text { ext }\end{array}$ \\
\hline $409-62$ & 1 & 1 & & 10R $5 / 8$ & red & 10R 4/8 & red & $\begin{array}{l}\text { slip int } \\
\text { and ext }\end{array}$ \\
\hline $409-62$ & 3 & 1 & & $\begin{array}{l}7.5 \text { YR } 6 / 4 \text { to } \\
2.5 \text { YR } 5 / 4\end{array}$ & $\begin{array}{l}\text { light brown to } \\
\text { reddish } \\
\text { brown }\end{array}$ & 10R 4/6 & red & $\begin{array}{l}\text { slip int } \\
\text { and ext }\end{array}$ \\
\hline $409-63$ & 1 & 1 & & too small & too small & too small & too small & ND \\
\hline $409-65$ & 1 & 1 & & $\begin{array}{c}7.5 \mathrm{YR} 6 / 4 \text { to } \\
10 \mathrm{R} 4 / 6\end{array}$ & $\begin{array}{l}\text { light brown to } \\
\text { red }\end{array}$ & 10R 4/6 & red & $\begin{array}{c}\text { slip int; } \\
\text { thin wash } \\
\text { ext } \\
\end{array}$ \\
\hline $409-72$ & 1 & 1 & & $5 \mathrm{YR} 4 / 4$ & $\begin{array}{c}\text { reddish } \\
\text { brown }\end{array}$ & 10R 4/8 & red & $\begin{array}{l}\text { slip int } \\
\text { and ext }\end{array}$ \\
\hline 409-76 & 1 & 1 & & 2.5YR 5/6 & red & 2.5YR 5/6 & red & $\begin{array}{l}\text { slip int } \\
\text { and ext }\end{array}$ \\
\hline 409-78 & 2 & 1 & & 10R 4/8 & red & 10R $4 / 8$ & red & $\begin{array}{l}\text { slip int } \\
\text { and ext }\end{array}$ \\
\hline $409-78$ & 1 & 1 & & $2.5 \mathrm{YR} 6 / 4$ & $\begin{array}{c}\text { light reddish } \\
\text { brown }\end{array}$ & 10R 5/6 & red & $\begin{array}{l}\text { slip int } \\
\text { and ext }\end{array}$ \\
\hline $409-84$ & 2 & 1 & & 10R $6 / 6$ & light red & $10 \mathrm{R} 4 / 6$ & red & $\begin{array}{l}\text { slip int } \\
\text { and ext }\end{array}$ \\
\hline $409-90$ & 1 & 1 & & 10R 5/6 & red & 10R 4/6 & red & $\begin{array}{l}\text { slip int } \\
\text { and ext }\end{array}$ \\
\hline $409-90$ & 1 & 1 & & 10R 5/6 & red & 10R 4/6 & red & $\begin{array}{l}\text { slip int } \\
\text { and ext }\end{array}$ \\
\hline 409-94 & 1 & 1 & & $5 \mathrm{YR} 6 / 4$ & $\begin{array}{l}\text { light reddish } \\
\text { brown }\end{array}$ & 10R 4/6 & red & $\begin{array}{l}\text { slip int } \\
\text { and ext }\end{array}$ \\
\hline $409-94$ & 1 & 1 & & $\begin{array}{c}\text { surface worn } \\
\text { away; fire cloud } \\
\text { to } 7.5 \mathrm{YR} 6 / 4\end{array}$ & $\begin{array}{l}\text { fire cloud to } \\
\text { light brown }\end{array}$ & 10R 4/8 & red & $\begin{array}{l}\text { slip int; } \\
\text { ext absent }\end{array}$ \\
\hline $409-98$ & 3 & 1 & & $\begin{array}{c}\text { surface worn } \\
\text { away; fire cloud } \\
\text { to } 7.5 \mathrm{YR} 6 / 4\end{array}$ & $\begin{array}{l}\text { fire cloud to } \\
\text { light brown }\end{array}$ & $10 \mathrm{R} 4 / 6$ & red & $\begin{array}{l}\text { slip int; } \\
\text { ext absent }\end{array}$ \\
\hline 409-106 & 1 & 1 & & fire cloud & fire cloud & 10R 4/6 & red & $\begin{array}{c}\text { slip int } \\
\text { only }\end{array}$ \\
\hline $409-106$ & 1 & 1 & & $2.5 \mathrm{YR} 6 / 4$ & light reddish & 10R $5 / 6$ & red & slip int \\
\hline
\end{tabular}




\begin{tabular}{|l|c|c|c|c|c|c|c|c|}
\hline & & & & & brown & & & and ext \\
\hline base & & & & & & & & \\
\hline $\begin{array}{l}409-90-1 \\
\text { to 6 }\end{array}$ & 1 & 3 & $\begin{array}{l}\text { SC-19 } \\
{[90-5]}\end{array}$ & 10R 5/6 & red & $10 \mathrm{R} 4 / 6$ & red & $\begin{array}{c}\text { slip int } \\
\text { and ext }\end{array}$ \\
\hline
\end{tabular}

Table 4. Slip placement and smudging on Ledbetter Red.

\begin{tabular}{|l|c|c|c|}
\hline & $14 \mathrm{SC} 1$ & $14 \mathrm{SC} 304$ & $14 \mathrm{SC} 409$ \\
\hline Slip int and ext & $15(63 \%)$ & $10(29 \%)$ & $51(89 \%)$ \\
\hline Slip int and thin red wash ext & 0 & $12(35 \%)$ & $3(5 \%)$ \\
\hline Slip int only (unslipped ext) & $5(21 \%)$ & $12(35 \%)$ & $3(5 \%)$ \\
\hline Smudged and polished int and exterior slip & $4(17 \%)$ & 0 & 0 \\
\hline Total sherds with both surfaces present and visible & 24 & 34 & 57 \\
\hline Total Ledbetter Red sherds in collection & 27 & 47 & 65 \\
\hline
\end{tabular}

Table 5. Oxidation data for Ledbetter Red ceramics from 14SC1.

\begin{tabular}{|l|l|l|l|l|l|l|}
\hline CAT NO & $\begin{array}{l}\text { Exterior } \\
\text { (oxidized) }\end{array}$ & $\begin{array}{l}\text { Exterior } \\
\text { (oxidized) } \\
\text { color }\end{array}$ & $\begin{array}{l}\text { Interior } \\
\text { (oxidized) }\end{array}$ & $\begin{array}{l}\text { Interior } \\
\text { (oxidized) } \\
\text { color }\end{array}$ & $\begin{array}{l}\text { Paste } \\
\text { (oxidized) }\end{array}$ & $\begin{array}{l}\text { Paste } \\
\text { (oxidized) } \\
\text { color }\end{array}$ \\
\hline 6742 & slip 10R 4/6 & red & $\begin{array}{l}\text { slip 2.5YR } \\
5 / 6\end{array}$ & red & $2.5 \mathrm{YR} 6 / 8$ & light red \\
\hline 8883 & $\begin{array}{l}\text { unslipped } \\
10 \mathrm{R} 5 / 6\end{array}$ & red & $10 \mathrm{R} 5 / 6$ & red & $10 \mathrm{R} 5 / 8$ & red \\
\hline 9904 & slip 10R 5/4 & weak red & $\begin{array}{l}\text { not visible on } \\
\text { fragment }\end{array}$ & ND & $10 \mathrm{YR} 7 / 4$ & $\begin{array}{l}\text { very pale } \\
\text { brown }\end{array}$ \\
\hline 13153 & slip 10R 4/4 & weak red & slip 10R 4/4 & weak red & $7.5 \mathrm{YR} 8 / 4$ & pink \\
\hline 21259 & $\begin{array}{l}\text { unslipped } \\
2.5 \mathrm{YR} 4 / 6\end{array}$ & red & slip 10R 4/6 & red & $10 \mathrm{R} 4 / 8$ & red \\
\hline 24297 & $\begin{array}{l}\text { slip 2.5YR } \\
4 / 6\end{array}$ & red & $\begin{array}{l}\text { slip 2.5YR } \\
4 / 6\end{array}$ & red & $2.5 \mathrm{YR} 4 / 8$ & red \\
\hline
\end{tabular}


Table 6. Oxidation data for Dismal River Gray Ware from 14SC1.

\begin{tabular}{|c|c|c|c|c|c|c|c|}
\hline CAT NO & $\begin{array}{l}\text { Petro. } \\
\text { sample no. }\end{array}$ & $\begin{array}{l}\text { INAA } \\
\text { sample no. }\end{array}$ & $\begin{array}{l}\text { INAA } \\
\text { group }\end{array}$ & $\begin{array}{l}\text { Paste } \\
\text { (original) }\end{array}$ & $\begin{array}{l}\text { Paste } \\
\text { (original) } \\
\text { color }\end{array}$ & $\begin{array}{l}\text { Paste } \\
\text { (oxidized) }\end{array}$ & $\begin{array}{l}\text { Paste } \\
\text { (oxidized) } \\
\text { color }\end{array}$ \\
\hline 7621 & SC-33 & 24 & 5 & 5YR 5/6 & $\begin{array}{l}\text { yellowish } \\
\text { red }\end{array}$ & $2.5 \mathrm{YR} 4 / 8$ & red \\
\hline 41965 & SC-30 & 50 & 3 & $2.5 Y 2.5 / 1$ & black & 7.5YR 7/6 & $\begin{array}{l}\text { reddish } \\
\text { yellow }\end{array}$ \\
\hline 43134 & SC-13 & 52 & 2 & $\begin{array}{l}7.5 \text { YR } 3 / 1 \\
\text { to } 7.56 / 6\end{array}$ & $\begin{array}{l}\text { very dark } \\
\text { gray to } \\
\text { reddish } \\
\text { yellow }\end{array}$ & 5YR 5/8 & $\begin{array}{l}\text { yellowish } \\
\text { red }\end{array}$ \\
\hline no cat \#1 & SC-5 & 7 & 1 & $\begin{array}{l}7.5 \mathrm{YR} 4 / 4 \\
\text { to } 7.5 \mathrm{YR} \\
2.5 / 1\end{array}$ & $\begin{array}{l}\text { brown to } \\
\text { black }\end{array}$ & 2.5 YR $5 / 6$ & red \\
\hline no cat \#2 & SC-6 & 8 & 3 & 5YR 6/6 & $\begin{array}{l}\text { reddish } \\
\text { yellow }\end{array}$ & 5YR 6/6 & $\begin{array}{l}\text { reddish } \\
\text { yellow }\end{array}$ \\
\hline no cat \#3 & SC-2 & 9 & 3 & $\begin{array}{l}\text { 5YR 5/6 to } \\
\text { GLEY1 } \\
2.5 / \mathrm{N}\end{array}$ & $\begin{array}{l}\text { yellowish } \\
\text { red to black }\end{array}$ & $2.5 \mathrm{YR} 4 / 6$ & red \\
\hline no cat \#4 & $\mathrm{SC}-3$ & 10 & 3 & 7.5 YR $6 / 4$ & light brown & 5YR 6/6 & $\begin{array}{l}\text { yellowish } \\
\text { red }\end{array}$ \\
\hline no cat \#6 & SC-43 & 11 & 3 & $\begin{array}{l}10 \mathrm{YR} 5 / 2 \\
\text { to } 10 \mathrm{YR} \\
3 / 1\end{array}$ & $\begin{array}{l}\text { grayish } \\
\text { brown to } \\
\text { very dark } \\
\text { gray }\end{array}$ & 7.5YR 7/6 & $\begin{array}{l}\text { reddish } \\
\text { yellow }\end{array}$ \\
\hline
\end{tabular}

